\title{
GEOLOGY, GEOCHEMISTRY AND PETROLOGICAL CHARACTERISTICS OF POTASH SALT UNITS FROM PZ2 AND PZ3 ZECHSTEIN (LATE PERMIAN) CYCLES IN POLAND
}

\section{Charakterystyka geochemiczno-petrologiczna ogniw potasonośnych cykli PZ2 i PZ3 cechsztynu w Polsce}

\section{Grzegorz CZAPOWSKI ${ }^{1}$, Hanna TOMASSI-MORAWIEC ${ }^{\mathbf{1}}$, Tomasz TOBOLA ${ }^{2} \&$ Joanna TADYCH ${ }^{3}$}

\author{
${ }^{I}$ Państwowy Instytut Geologiczny-Państwowy Instytut Badawczy; \\ ul. Rakowiecka 4, 00-975 Warszawa; \\ e-mail: grzegorz.czapowski@pgi.gov.pl,hanna.tomassi-morawiec@pgi.gov.pl \\ ${ }^{2}$ AGH Akademia Górniczo-Hutnicza, Wydziat Geologii, Geofizyki i Ochrony Środowiska; \\ al.A. Mickiewicza 30,30-059 Kraków; e-mail: tob@geolog.geol.agh.pl \\ ${ }^{3}$ Inowrocławskie Kopalnie Soli „Solino” SA, ul. Świętego Ducha 26A, 88-100 Inowrocław; \\ e-mail: joanna.tadych@solino.pl
}

\begin{abstract}
Analysis of archive and published geological, geochemical and petrological data on composition of potash-bearing units (Older Potash [K2] and Younger Potash [K3]) of the Polish Zechstein (Late Permian) sections (mainly sampled profiles form three salt diapirs located in central Poland: Góra, Kłodawa, Mogilno, and additionally for petrology from Inowrocław diapir as well as some data from the stratiform potash occurrences in the Foresudetic area in SW Poland) enabled to define content intervals and data statistic of main chemical components of both potash units as well as a type and content of determined evaporate minerals composed them.
\end{abstract}

Key words: potash-magnesium salts, petrology, geochemistry, Late Permian (Zechstein), Poland

Treść: Praca jest próbą syntetycznego przedstawienia charakterystyki wykształcenia, geochemii, składu mineralnego i petrograficznego późnopermskich (cechsztyńskich) utworów potasonośnych, budujących dwa wydzielenia litostratygraficzne - starszą (K2) i młodszą (K3) sól potasową. Charakterystykę oparto na analizie archiwalnych i publikowanych danych, odnoszących się głównie do profili z trzech wysadów solnych z obszaru centralnej Polski: Góra, Kłodawa i Mogilno, oraz w przypadku danych petrograficznych - również do wysadu Inowrocław. Ponadto wykorzystano dane dotyczące pokładowych wystąpień soli potasowo-magnezowych na obszarze przedsudeckim.

Słowa kluczowe: sole potasowo-magnezowe, petrologia, geochemia, późny perm (cechsztyn), Polska 


\section{INTRODUCTION}

Potash-bearing formations of the Polish Zechstein deposits (lithostratigraphic units determined to be Older Potash [K2] and Younger Potash [K3]) constitute a constant element builded the evaporate successions of the PZ2 (Stassfurt) and the PZ3 (Leine) cycles. They represent both an attractive raw material and an undesired rock in a case of storage cavern leaching.

Presented the geochemical and petrological characteristics of both potash units intended to demonstrate synthetically their current knowledge status, has based on the analyses of both archival and published results of geochemical identification of samples collected from the salt diapirs in the Kujawy Region (Kłodawa, Góra, and Mogilno), as well as both archival and published data from the Fore-Sudetic area (Czapowski \& Bukowski 2009, with references therein). Because of various sampling and analytical methods applied during the past nearly 60 years it was difficult to compare the research results, so, consequently, the presented final geochemical characteristics of both formations is very general but it summarized the all accessible data. Petrological characteristics of both types of formations was based on archival and published data, as well as on observations of available thin plates. In the review the influence of epigenetic phenomena, discussed in detail in other publication, became omitted (e.g. Hanczke 1969, Stańczyk-Stasik 1976).

\section{GENERAL CONDITIONS OF OCCURRENCE OF THE ZECHSTEIN POTASH-BEARING FORMATIONS IN POLAND}

Primary, mainly chloride potash-magnesium salts constitued - with the accompanying halite interbeds - two lithostratigraphic units of the Polish Zechstein profile: the Older Potash [K2] and the Younger Potash [K3], correlated with their equivalents in the Zechstein sections from the western part of European Permian Basin (EPB: Doornenbal \& Stevenson 2010; Wagner 1994). These salts are consisted mainly of chloride minerals as carnallite and sylvine and the mixed chloride-sulphate ones as kainite, became partly replaced by sulphates (kieserite, polyhalite, and epsomite). The probable primary thickness of these units, ranging from several to several dozens of metres (Wagner 1994), with the maximum of $120 \mathrm{~m}$ resulted from tectonic repetitions in case of K2 and over $170 \mathrm{~m}$ for K3 (Misiek 1997). Their recent extent are similar and they are located in the axial part of the Permian Basin, from the Łódź Trough to Western Pomerania, entering southwards onto the Fore-Sudetic Monocline down to the Zielona Góra area of (Fig. 1).

There were not commented the early diagenetic K-Mg sulphate salts of the polyhalite type, occurring as stratiforms, lenses, and impregnates, within chlorides and sulphates of the PZ1 cycle in northern Poland (Czapowski \& Bukowski 2009, with references), as well as secondary vein formations and impregnates, occurring within the folded Zechstein salt series in salt diapirs. 


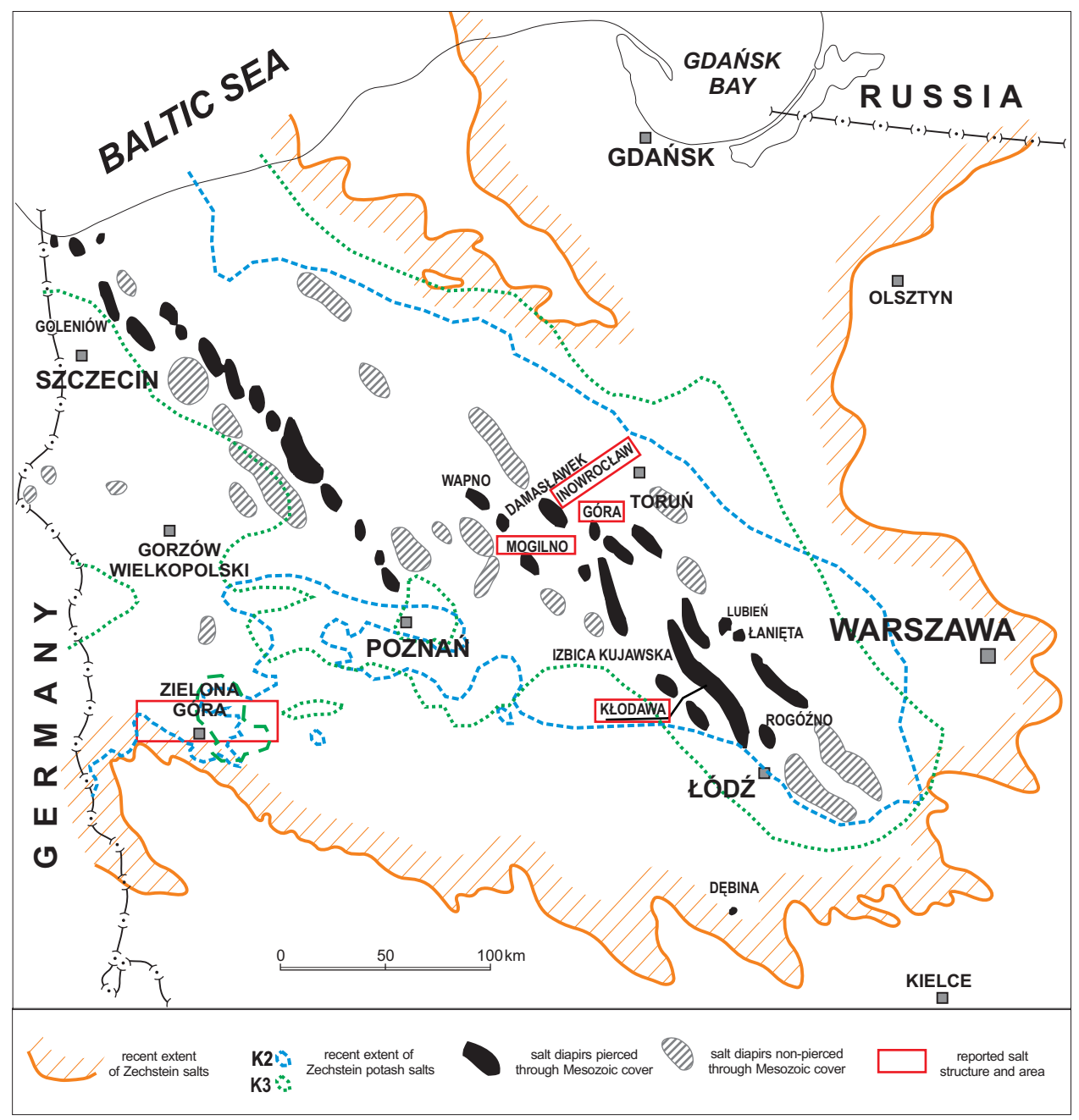

Fig. 1. Locations of the studied salt structures and areas on the background of the present extent of Zechstein salts (after Czapowski et al. 1990, Czapowski 1994, Czapowski \& Bukowski 2009)

Fig. 1. Lokalizacja badanych struktur solnych i obszarów na tle obecnego zasięgu występowania soli cechsztynu (wg Czapowski et al. 1990, Czapowski 1994, Czapowski \& Bukowski 2009)

\section{METHODOLOGY OF GEOCHEMICAL AND PETROLOGICAL STUDIES}

The chemical and mineral composition were analyzed in two lithostratigraphic units: K2 (severol decimeters to $12 \mathrm{~m}$ thick) and K3 (20-35 m thick), contained primary potash-magnesium salts and occurred within three salt diapirs in the Kujawy Region. 
These units are listed below:

- Kłodawa (units K2 and K3 - Werner et al. 1962, Tomassi-Morawiec et al. 2008a, 2009);

- Góra (unit K2 - material from G-30 borehole; unit K3 - material from G-39 borehole);

- Mogilno (units K2 and K3 - material from M-24 borehole).

Statistical analysis of geochemical data was done for:

- unit K2: 114 channel samples and 50 point samples,

- unit K3: 135 channel samples and 238 point samples.

For comparative purposes, chemical composition was presented (based on the literature and archival data) for equivalent formations from the Fore-Sudetic area.

\section{Determination of the chemical composition of salt samples from the Kłodawa diapir}

Determination of the chemical composition of salt samples, taken from the core material from the exploration boreholes (Tab. 1), drilled to document the rock salt and potash-magnesium salts resources in the Kłodawa diapir became realized before 1962 by two facilites (Werner 1962):

- Chemical Laboratory of the "Kłodawa" Salt Mine (lchKłodawa): channel samples (taken from core sections with the length $0.2-2.4 \mathrm{~m}$ ),

- Central Laboratory of the Geological Institute (GLIG): point samples.

In both types of the samples, the content of the following components were determined: water-insoluble parts, $\mathrm{H}_{2} \mathrm{O}, \mathrm{Cl}, \mathrm{SO}_{4}, \mathrm{CaO}, \mathrm{K}_{2} \mathrm{O}$, and $\mathrm{MgO}$. Samples weighing ca. $100 \mathrm{~g}$ were crushed to the grain fraction of less than $0.2 \mathrm{~mm}$ and subjected to analytical procedures:

- determination of water-insoluble part content: dissolution of a sample aliquot in hot water during $0.5 \mathrm{~h}$ (lchKłodawa) or $24 \mathrm{hrs}$ (GLIG), and weighing the solid residue;

- determination of $\mathrm{H}_{2} \mathrm{O}$ content: determination of the total content of crystalline and surface water by calculation of the difference in weight of an aliquot baked in the temperature of $300^{\circ} \mathrm{C}$ (lchKłodawa) or determination of humidity by drying of an aliquot weighing $1 \mathrm{~g}$ in the temperature of $140^{\circ} \mathrm{C}$ until its constant weight is reached (GLIG);

- determination of $\mathrm{Cl}$ content: titration with silver nitrate (Mohr's method);

- determination of $\mathrm{SO}_{4}$ content: titration with barium chloride (lchKłodawa); measuring extinction nefelometrically with the Pulfrich photometer (GLIG);

- determination of content $\mathrm{CaO}$ : titration with disodium edetate;

- determination of $\mathrm{K}_{2} \mathrm{O}$ content: perchlorate method (lchKłodawa); flame photometry method with a Zeiss IIIB photometer (GLIG);

- determination of $\mathrm{MgO}$ content: as a total volume, determined by the leaching method according to the equation: $\mathrm{MgCl}_{2}+2 \mathrm{NaOH}=\mathrm{Mg}(\mathrm{OH})_{2}+2 \mathrm{NaCl}$ (lchKłodawa); titration with disodium edetate (GLIG);

- Na content was calculated from the difference of the anion or cation mvals;

- determination of bromine content: titration after the d'Ans' method.

The mineral content of the samples was determined by conversion of the content of the specified components into their proportions in the basic salt minerals. 


\section{Table (Tabela) 1}

Number and type of geochemical samples collected from the Zechstein potash units

(K2 and K3) from the Kłodawa salt diapir (Werner et al. 1962)

Liczba i rodzaj próbek do badań geochemicznych pobranych z cechsztyńskich ogniw soli potasowo-magnezowych (K2 i K3) w profilach otworów wiertniczych na wysadzie solnym Kłodawa (Werner et al. 1962)

\begin{tabular}{|c|c|c|c|c|}
\hline Borehole & $\begin{array}{c}\mathrm{K} 2 \text { unit } \\
\text { (depth interval } \\
\text { in } \mathrm{m} \text { ) }\end{array}$ & $\begin{array}{l}\text { Number and type } \\
\text { of samples } \\
\text { (for channel } \\
\text { samples the interval } \\
\text { of sampling in } \mathrm{m} \text { ) }\end{array}$ & $\begin{array}{c}\mathrm{K} 3 \text { unit } \\
\text { (depth interval } \\
\text { in } \mathrm{m} \text { ) }\end{array}$ & $\begin{array}{l}\text { Number } \\
\text { and type of samples } \\
\text { (for channel } \\
\text { samples the interval } \\
\text { of sampling in } \mathrm{m} \text { ) }\end{array}$ \\
\hline Kłodawa K-1 & - & - & $457.5-671.5$ & 28 point samples \\
\hline Kłodawa K-6 & - & - & 687.0 & 5 point samples \\
\hline \multirow{3}{*}{ Kłodawa K-10 } & $1355.3-1359.1$ & $\begin{array}{c}4 \text { channel samples } \\
(0.2-0.3)\end{array}$ & \multirow{3}{*}{-} & \multirow{3}{*}{-} \\
\hline & $1459.5-1466.2$ & $\begin{array}{c}3 \text { channel samples } \\
(0.2-2.4)\end{array}$ & & \\
\hline & $1441.8-1443.8$ & $\begin{array}{c}1 \text { channel sample } \\
\text { (2.0) }\end{array}$ & & \\
\hline Kłodawa K-11 & - & - & $1208.0-1257.0$ & 9 point samples \\
\hline Kłodawa K-24 & - & - & $680.6-700.0$ & $\begin{array}{c}26 \text { channel samples } \\
(0.6-1.0)\end{array}$ \\
\hline $\begin{array}{l}\text { Rycerzew } \\
\text { K-25 }\end{array}$ & - & - & $740.0-849.7$ & $\begin{array}{l}109 \text { channel } \\
\text { samples } \\
(0.6-1.0)\end{array}$ \\
\hline \multirow{2}{*}{$\begin{array}{l}\text { Marcjanowo } \\
\text { K-33 }\end{array}$} & $808.9-828.4$ & $\begin{array}{c}15 \text { channel samples } \\
(0.2-0.9)\end{array}$ & \multirow{2}{*}{-} & \multirow{2}{*}{-} \\
\hline & $855.5-883.7$ & $\begin{array}{c}14 \text { channel samples } \\
(1.0-1.5)\end{array}$ & & \\
\hline \multirow{2}{*}{ Sobótka K-32 } & $414.4-438.0$ & $\begin{array}{c}15 \text { channel samples } \\
(0.5-1.0)\end{array}$ & \multirow{2}{*}{-} & \multirow{2}{*}{-} \\
\hline & $591.1-896.0$ & $\begin{array}{c}48 \text { channel samples } \\
(0.5-1.0)\end{array}$ & & \\
\hline Sobótka K-52 & $301.9-357.0$ & 11 point samples & - & - \\
\hline
\end{tabular}

Statistical parameters of determined chemical components and calculated mineral components were listed in tables 2-5. 


\begin{tabular}{|c|c|c|c|c|c|c|c|c|c|c|c|c|c|c|c|c|c|}
\hline \multirow{15}{*}{\multicolumn{2}{|c|}{ 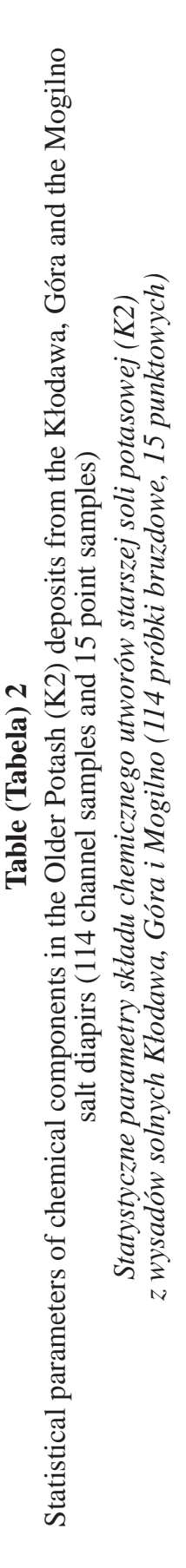 }} & \multirow{13}{*}{ 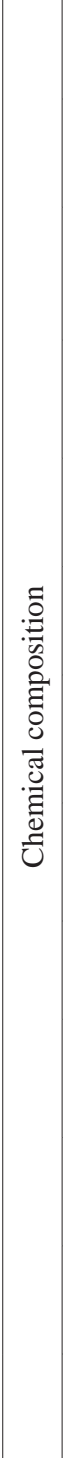 } & $\bar{D}$ & Е & \multirow{14}{*}{ 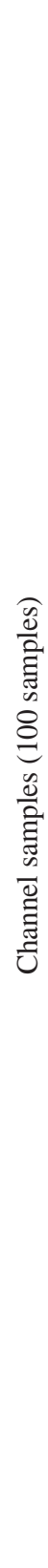 } & 8 & $\stackrel{8}{\varrho}$ & 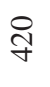 & fo & 守 & $\bar{m}$ & \multirow{14}{*}{ 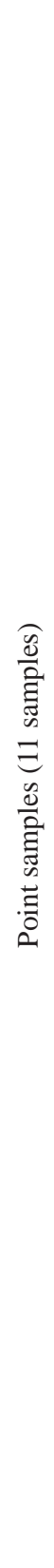 } & 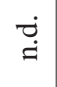 & $\stackrel{\vec{j}}{\ddot{\pi}}$ & $\stackrel{\check{g}}{\dot{g}}$ & ¿ேं & 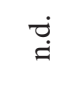 \\
\hline & & & O) & $b^{\circ}$ & & $\begin{array}{l}n \\
0 \\
0\end{array}$ & $\stackrel{\infty}{\stackrel{0}{\Sigma}}$ & $\underset{-}{\widehat{\sigma}}$ & $\stackrel{\circ}{\rightarrow}$ & $\stackrel{n}{\circ}$ & 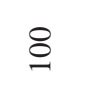 & & $\exists$ & $\stackrel{\check{a}}{2}$ & $\stackrel{\sharp}{r}$ & $\begin{array}{l} \pm \\
\text { r. }\end{array}$ & 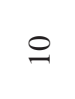 \\
\hline & & & 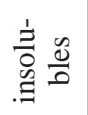 & $b^{\circ}$ & & $\begin{array}{l}\overline{0} \\
\dot{0}\end{array}$ & $\begin{array}{l}\infty \\
\stackrel{+}{+} \\
\dot{f}\end{array}$ & $\stackrel{\Omega}{\hat{i}}$ & $\stackrel{+}{n}$ & $\mid \begin{array}{l}\infty \\
0 \\
0 \\
0\end{array}$ & ลे & & ָָ & 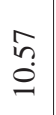 & $\begin{array}{l}\underset{+}{+} \\
-\end{array}$ & $\begin{array}{l}\overline{0} \\
0\end{array}$ & $=$ \\
\hline & & & 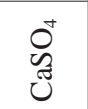 & $b^{\circ}$ & & $\stackrel{0}{0}$ & 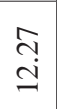 & $\stackrel{\infty}{\stackrel{\infty}{\oplus}}$ & $\begin{array}{l}\stackrel{8}{0} \\
\dot{m}\end{array}$ & ત્ત & 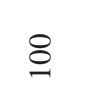 & & ले & $\begin{array}{l}n \\
6 \\
6\end{array}$ & $\underset{\mathrm{i}}{\mathrm{i}}$ & $\stackrel{\Omega}{\Omega}$ & $=$ \\
\hline & & & $O_{\mathscr{S}}^{+}$ & $b^{\circ}$ & & $\stackrel{\check{I}}{\dot{I}}$ & $\stackrel{\dot{\Xi}}{\dot{\Xi}}$ & 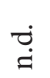 & $\stackrel{\check{I}}{\dot{I}}$ & 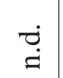 & 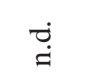 & & $\stackrel{\check{g}}{=}$ & $\stackrel{\ddot{g}}{\ddot{g}}$ & $\stackrel{\dot{d}}{\dot{g}}$ & $\stackrel{\ddot{g}}{\dot{I}}$ & $\stackrel{\underset{\dot{d}}{g}}{ }$ \\
\hline & & & Uే & $b^{\circ}$ & & $\stackrel{\check{g}}{\dot{g}}$ & $\stackrel{\dot{g}}{\dot{=}}$ & ذ્ذ & $\stackrel{\dot{I}}{\dot{I}}$ & $\dot{\dot{g}}$ & ت્ટ் & & $\stackrel{\dot{d}}{\dot{d}}$ & $\stackrel{\check{g}}{\stackrel{d}{d}}$ & $\stackrel{\check{g}}{\dot{g}}$ & $\underset{\dot{I}}{\check{I}}$ & 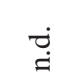 \\
\hline & & & $\begin{array}{l}0^{+} \\
W^{\infty} \\
\sum^{\infty}\end{array}$ & $b^{\circ}$ & & $\stackrel{=}{0}$ & $\begin{array}{l}\stackrel{\Xi}{\Delta} \\
\text { त. }\end{array}$ & $\stackrel{\text { ণे }}{+}$ & $\underset{\dot{r}}{\vec{r}}$ & $\underset{\sim}{\stackrel{f}{-}}$ & $\hat{\sigma}$ & & $\overrightarrow{\tilde{o}}$ & 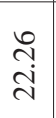 & $\begin{array}{l}n \\
n \\
\infty\end{array}$ & $\begin{array}{c}\bar{\sigma} \\
\dot{r}\end{array}$ & $=$ \\
\hline & & & $\frac{\overrightarrow{U^{N}}}{\sum^{\infty}}$ & $\delta^{\circ}$ & & $\begin{array}{l}\bullet \\
\stackrel{0}{0}\end{array}$ & $\begin{array}{l}\infty \\
\infty \\
\infty\end{array}$ & $\bar{a}$ & $\begin{array}{l}\infty \\
\infty \\
0\end{array}$ & ñ & ஜ & & 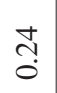 & $\stackrel{m}{0}$ & ते & & $N$ \\
\hline & & & $\sum^{\infty}$ & $b^{0}$ & & $\stackrel{\dot{\Xi}}{\leftrightarrows}$ & 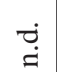 & $\stackrel{\check{g}}{\ddot{g}}$ & $\stackrel{ن}{\dot{x}}$ & $\stackrel{\dot{d}}{\dot{g}}$ & 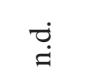 & & $\stackrel{\check{d}}{\dot{g}}$ & 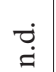 & & 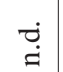 & 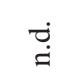 \\
\hline & & & $\begin{array}{l}0^{+} \\
\mathscr{N}^{+} \\
\text {| }\end{array}$ & $b^{\circ}$ & & $\stackrel{n}{0}$ & $\stackrel{m}{\varrho}$ & లి & $\hat{m}$ & $\stackrel{\stackrel{n}{f}}{-}$ & $\stackrel{\sim}{\sim}$ & & ָุ & $\stackrel{\tilde{m}}{ \pm}$ & $\stackrel{i}{i}$ & $\stackrel{m}{\dot{r}}$ & $\infty$ \\
\hline & & & $\underset{\forall}{\circlearrowright}$ & $b^{\circ}$ & & $\frac{0}{0}$ & 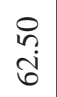 & $\begin{array}{l}8 \\
\circ\end{array}$ & 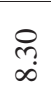 & $\begin{array}{l}\tilde{\infty} \\
\dot{\sigma}\end{array}$ & 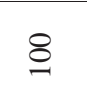 & & $\stackrel{n}{n}$ & $\stackrel{n}{\stackrel{2}{r}}$ & 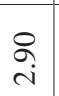 & $\underset{\mathfrak{n}}{\mathfrak{\sigma}}$ & $=$ \\
\hline & & & $\forall$ & $b^{\circ}$ & & $\stackrel{\check{g}}{\dot{I}}$ & $\stackrel{\check{g}}{\dot{g}}$ & ¿્ય & $\stackrel{\check{I}}{\dot{I}}$ & $\dot{\dot{g}}$ & ت્ & & $\stackrel{\check{g}}{=}$ & $\stackrel{\check{g}}{=}$ & 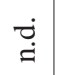 & $\underset{\dot{g}}{\dot{d}}$ & 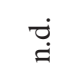 \\
\hline & & & $\begin{array}{l}\underset{\Xi}{Z} \\
\bar{Z}\end{array}$ & $b^{\circ}$ & & $\begin{array}{l}0 \\
\stackrel{0}{0} \\
\stackrel{i}{1}\end{array}$ & $\stackrel{-}{\infty}$ & 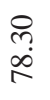 & $\underset{n}{n}$ & $\begin{array}{l}m \\
\hat{\sigma} \\
\dot{\infty}\end{array}$ & $\stackrel{8}{8}$ & & $\begin{array}{l}\stackrel{2}{2} \\
\stackrel{i}{n}\end{array}$ & $\begin{array}{l}\dot{0} \\
\dot{\sigma} \\
\sigma\end{array}$ & $\begin{array}{l}\vec{\nabla} \\
\stackrel{r}{r}\end{array}$ & $\begin{array}{l}n \\
\stackrel{n}{\tau}\end{array}$ & $=$ \\
\hline & & & 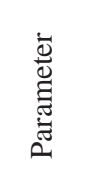 & & & 寻 & $\begin{array}{l}\underset{\Xi}{\Xi} \\
\stackrel{\Xi}{*}\end{array}$ & 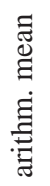 & 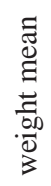 & 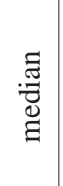 & 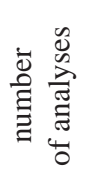 & & $\dot{\Xi}$ & 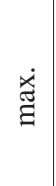 & 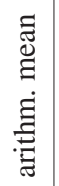 & 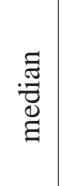 & 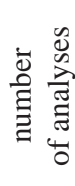 \\
\hline & & & 总 & & & & & & & & 菏 & & & & & & \\
\hline
\end{tabular}




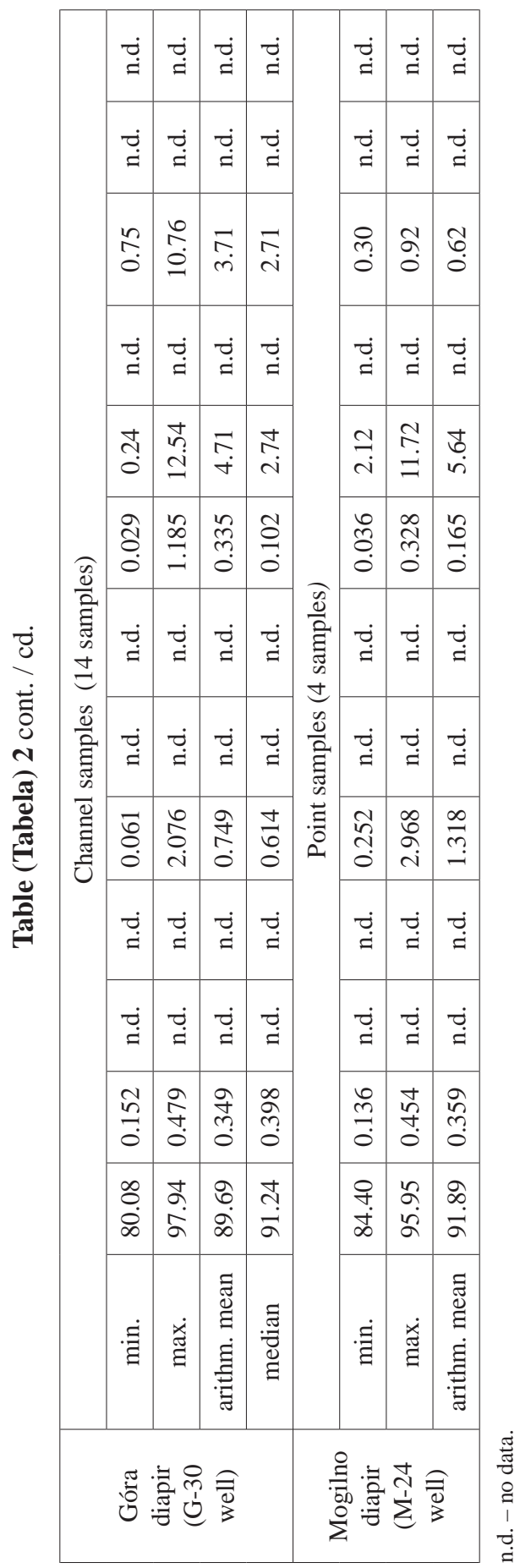

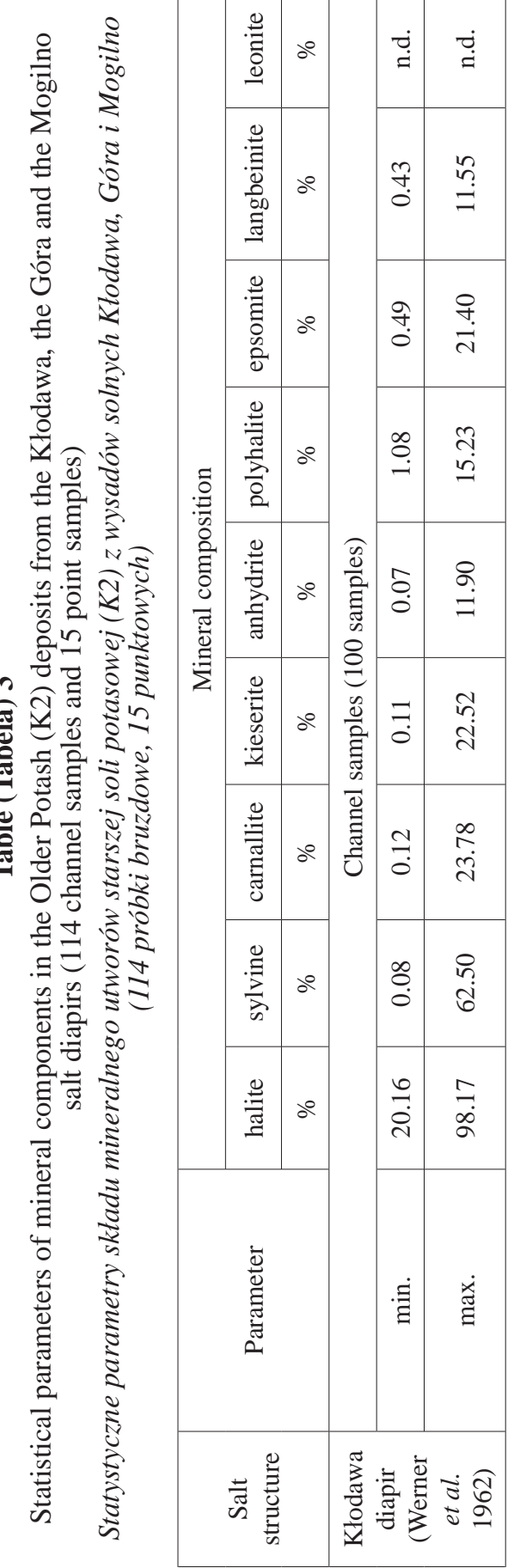




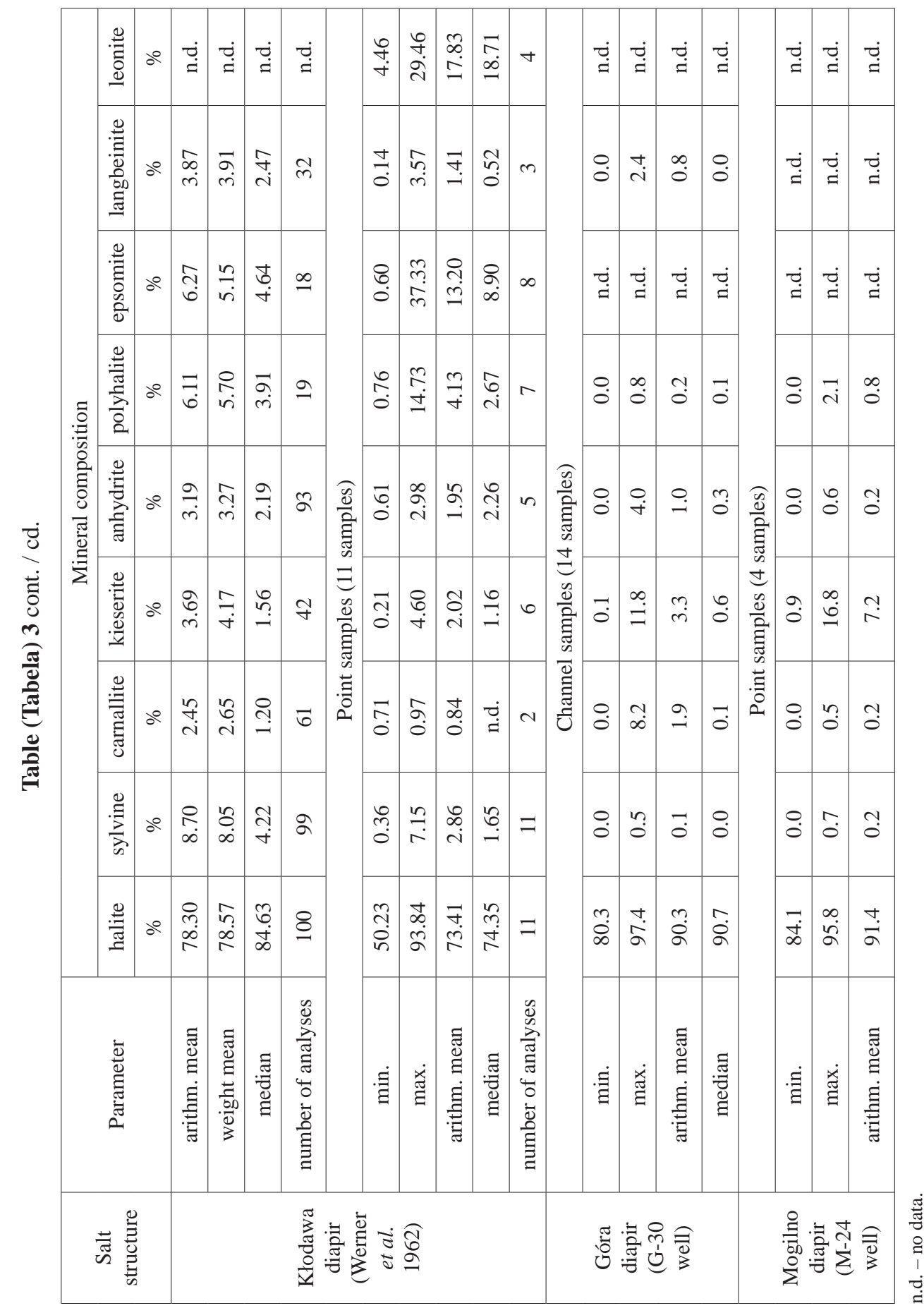




\begin{tabular}{|c|c|c|c|c|c|c|c|c|c|c|c|c|c|c|c|c|}
\hline 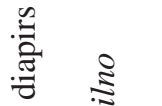 & & $\bar{\oplus}$ & $0^{\circ}$ & & $\begin{array}{l}\widehat{\widehat{D}} \\
\stackrel{0}{0}\end{array}$ & $\begin{array}{l}2 \\
\infty \\
0\end{array}$ & 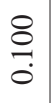 & $\stackrel{1}{\stackrel{0}{0}}$ & $\begin{array}{l}\hat{0} \\
\dot{0}\end{array}$ & $\triangleright$ & & $\stackrel{\check{d}}{\ddot{g}}$ & $\stackrel{\ddot{I}}{\dot{\pi}}$ & $\stackrel{\dot{d}}{\dot{g}}$ & $\stackrel{\check{d}}{\dot{d}}$ & $\stackrel{\check{g}}{\check{g}}$ \\
\hline 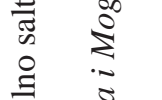 & & $\begin{array}{l}\text { O } \\
\text { II }\end{array}$ & $b^{\circ}$ & & $\stackrel{n}{\stackrel{n}{0}}$ & $\begin{array}{l}\curvearrowright \\
\infty \\
i\end{array}$ & f. & $\underset{\infty}{\mathbb{\infty}}$ & 古 & $\stackrel{n}{2}$ & & $\stackrel{0}{0}$ & \begin{tabular}{l}
0 \\
\multirow{1}{*}{} \\
$\dot{\varphi}$
\end{tabular} & $\begin{array}{l}\tilde{N} \\
\infty \\
\infty\end{array}$ & $\vec{r}$ & શे \\
\hline 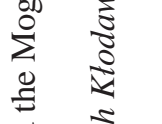 & & 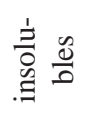 & $b^{0}$ & & $\ddot{\Xi}$ & $\begin{array}{l}\infty \\
\infty \\
\dot{n} \\
\end{array}$ & $\stackrel{0}{0}$ & $\underset{\sim}{\nexists}$ & $\tilde{y}$ & $\stackrel{\infty}{=}$ & & $\ddot{\Xi}$ & $\begin{array}{l}\stackrel{?}{\stackrel{2}{\Xi}} \\
=\end{array}$ & $\vec{i}$ & $\overrightarrow{0}$ & $\stackrel{n}{\sim}$ \\
\hline 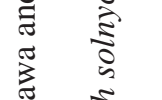 & & $\begin{array}{l}0^{+} \\
\text {ల్ } \\
\text { Uి }\end{array}$ & $b^{\circ}$ & & ¿̊. & $\stackrel{i}{a}$ & $\stackrel{\overbrace{}}{\sim}$ & $\stackrel{g}{\stackrel{g}{g}}$ & $\begin{array}{l}8 \\
0\end{array}$ & $\stackrel{さ}{\beth}$ & & $\stackrel{\Xi}{0}$ & ?̊n & $\stackrel{\infty}{\infty}$ & $\hat{\sigma}$ & こ \\
\hline 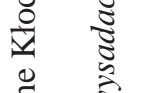 & & $\stackrel{0}{+}_{\mathscr{S}}^{+}$ & $b^{0}$ & & 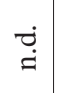 & $\stackrel{\dot{\Xi}}{\dot{g}}$ & $\stackrel{\vec{j}}{\ddot{g}}$ & வ் & $\stackrel{\dot{\Perp}}{\check{\pi}}$ & ذ્ّ & & $\stackrel{\check{g}}{\dot{j}}$ & $\stackrel{\dot{\jmath}}{\dot{=}}$ & $\stackrel{\dot{\Xi}}{\dot{\Xi}}$ & $\stackrel{\check{g}}{\ddot{g}}$ & $\stackrel{\check{g}}{=}$ \\
\hline 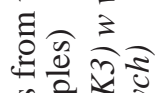 & : & $\tilde{U}$ & $b^{\circ}$ & (n) & 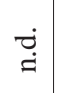 & $\stackrel{\dot{d}}{\dot{g}}$ & $\stackrel{\check{\dot{d}}}{=}$ & $\stackrel{\text { ப் }}{=}$ & $\stackrel{\dot{g}}{\dot{e}}$ & $\stackrel{\check{g}}{\dot{g}}$ & & $\stackrel{\check{\dot{d}}}{\dot{d}}$ & 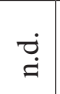 & $\stackrel{\dot{d}}{\dot{g}}$ & $\stackrel{\text { ப் }}{\dot{g}}$ & 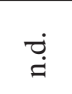 \\
\hline 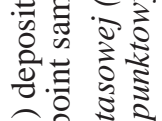 & 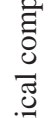 & $\begin{array}{l}0^{+} \\
W_{2}^{\infty 0} \\
\sum\end{array}$ & $b^{\circ}$ & 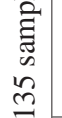 & $\stackrel{n}{0}$ & $\frac{0}{\dot{n}}$ & $\begin{array}{l}\infty \\
\infty \\
\dot{ \pm}\end{array}$ & त̂ & $\begin{array}{l}\stackrel{n}{f} \\
\dot{ \pm}\end{array}$ & $\bar{a}$ & 雍 & $\begin{array}{l}\text { J } \\
0\end{array}$ & $\begin{array}{l}\infty \\
\infty \\
\infty \\
\infty\end{array}$ & 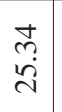 & $\begin{array}{l}8 \\
\stackrel{1}{+}\end{array}$ & \& \\
\hline 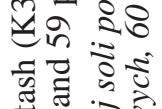 & है & $\sum_{D_{0}^{N}}^{N}$ & $b^{\circ}$ & 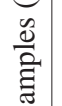 & $\begin{array}{l}\vec{b} \\
0\end{array}$ & ஓे & $\stackrel{n}{r}$ & $\begin{array}{l}n \\
\infty \\
0 \\
0\end{array}$ & $\begin{array}{l}+ \\
\infty \\
\dot{n}\end{array}$ & 西 & $\frac{n}{\tilde{0}}$ & 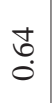 & 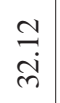 & శై & $\stackrel{\infty}{\infty}$ & $\bar{\sim}$ \\
\hline 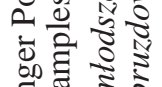 & & $\sum^{\infty}$ & $b^{\circ}$ & $\begin{array}{l}\bar{\Xi} \\
\text { छ్ }\end{array}$ & $\stackrel{\square}{\dot{I}}$ & $\dot{\ddot{g}}$ & 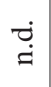 & $\stackrel{\ddot{̣}}{\ddot{g}}$ & $\mid \stackrel{\check{g}}{\dot{I}}$ & $\ddot{\check{g}}$ & . & $\stackrel{\check{g}}{\dot{g}}$ & $\stackrel{\dot{\Xi}}{\dot{g}}$ & $\stackrel{\vec{\Perp}}{\dot{\Xi}}$ & $\stackrel{\ddot{g}}{\ddot{g}}$ & $\stackrel{\check{I}}{=}$ \\
\hline 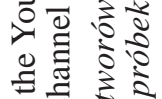 & & $\begin{array}{l}0^{+} \\
\tilde{n}^{1}\end{array}$ & $0^{0}$ & & 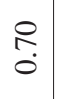 & $\stackrel{\cap}{+}$ & $\underset{\mathrm{f}}{\mathrm{i}}$ & in & $\hat{i}$ & 은 & & ָ̊. & $\begin{array}{l}\stackrel{尺}{+} \\
\stackrel{+}{+}\end{array}$ & $\begin{array}{l}\infty \\
\stackrel{0}{0} \\
\stackrel{2}{-}\end{array}$ & $\begin{array}{l}\stackrel{2}{2} \\
\stackrel{n}{n}\end{array}$ & $r$ \\
\hline 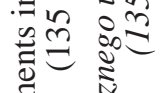 & & $\vec{v}$ & $b^{\circ}$ & & 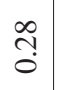 & $\begin{array}{l}\text { J } \\
\stackrel{d}{d}\end{array}$ & $\begin{array}{l}\infty \\
+ \\
\infty \\
\infty\end{array}$ & $\begin{array}{l}0 \\
\infty \\
\infty\end{array}$ & 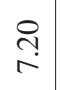 & さે & & $\begin{array}{c}0 \\
0\end{array}$ & 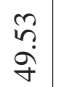 & $\begin{array}{l}\infty \\
\stackrel{m}{m}\end{array}$ & $\begin{array}{l}n \\
\ddot{n} \\
\ddot{n}\end{array}$ & 우 \\
\hline 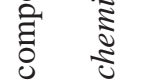 & & $\forall$ & $b^{\circ}$ & & $\stackrel{\overrightarrow{\dot{d}}}{=}$ & $\stackrel{\vec{d}}{\dot{g}}$ & $\stackrel{\check{d}}{\dot{d}}$ & تُ & $\stackrel{\check{g}}{\dot{g}}$ & 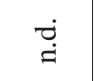 & & $\stackrel{\overrightarrow{\dot{j}}}{\dot{g}}$ & $\stackrel{\dot{\Xi}}{\dot{\Xi}}$ & $\stackrel{\dot{\dot{g}}}{\dot{g}}$ & $\stackrel{\check{g}}{\dot{g}}$ & ¿્ય \\
\hline 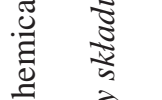 & & $\begin{array}{l}\overline{\tilde{Z}} \\
\bar{Z}\end{array}$ & $b^{0}$ & & $\begin{array}{l}\tilde{n} \\
\ddot{n}\end{array}$ & ๙ે & $\begin{array}{l}0 \\
\stackrel{1}{i} \\
\text { b }\end{array}$ & $\frac{9}{8}$ & $\stackrel{\varrho}{\ddot{r}}$ & $\stackrel{n}{2}$ & & $\stackrel{?}{=}$ & 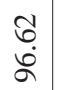 & $\begin{array}{l}\stackrel{a}{+} \\
\infty \\
\infty\end{array}$ & 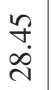 & 구 \\
\hline 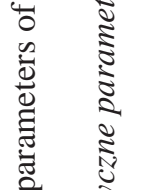 & & 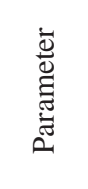 & & & 离 & 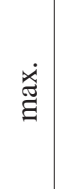 & 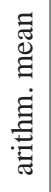 & 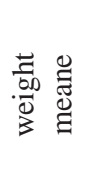 & 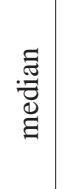 & 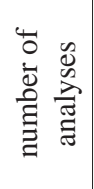 & & 竝 & 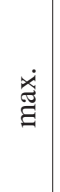 & 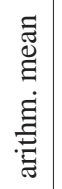 & : & 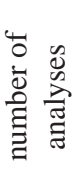 \\
\hline 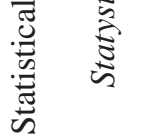 & & 总 & & & & & & & & 离 & & & & & & \\
\hline
\end{tabular}




\begin{tabular}{|c|c|c|c|c|c|c|c|}
\hline \multirow{13}{*}{ 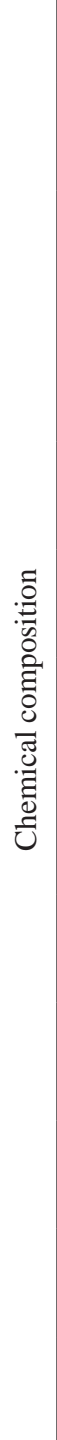 } & $\ddot{\oplus}$ & $0^{\circ}$ & \multirow{14}{*}{ 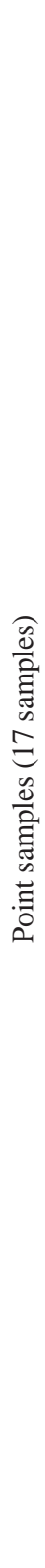 } & $\stackrel{\check{I}}{\ddot{I}}$ & $\stackrel{\check{d}}{\dot{I}}$ & & تُ \\
\hline & $\underset{\text { O }}{\text { O }}$ & $\delta^{\circ}$ & & $\stackrel{\vec{\nexists}}{\not}$ & 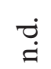 & $\stackrel{\check{d}}{\not}$ & $\stackrel{\dot{J}}{=}$ \\
\hline & $\begin{array}{l}\stackrel{1}{\Rightarrow} \\
0 \\
0 \\
.\end{array}$ & $0^{\circ}$ & & $\stackrel{8}{\circ}$ & $\frac{\infty}{m}$ & $\stackrel{\text { ¿ }}{\circ}$ & $\stackrel{\sigma}{\sigma}$ \\
\hline & $\begin{array}{l}0^{+} \\
\mathscr{J} \\
\tilde{U}\end{array}$ & $\delta^{\circ}$ & & $\stackrel{\ddot{g}}{=}$ & $\stackrel{\dot{\Xi}}{\dot{g}}$ & $\stackrel{\dot{\Xi}}{\dot{I}}$ & $\stackrel{\check{g}}{=}$ \\
\hline & $\overbrace{\mathscr{\Omega}}^{+}$ & $b^{0}$ & & $\underset{\sim}{\stackrel{\Delta}{0}}$ & $\begin{array}{l}\overline{6} \\
\dot{\sigma}\end{array}$ & $\stackrel{n}{\stackrel{n}{c}}$ & $\stackrel{\text { g }}{\text {. }}$ \\
\hline & $\tilde{U}$ & $\delta^{0}$ & & 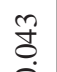 & ? & $\stackrel{\infty}{\stackrel{\infty}{+}}$ & $\underset{\Xi}{\Xi}$ \\
\hline & $\begin{array}{l}0^{+} \\
W_{n}^{\infty} \\
\sum^{\infty}\end{array}$ & $\delta^{\circ}$ & & $\stackrel{\check{I}}{=}$ & $\stackrel{\check{g}}{\dot{I}}$ & 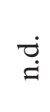 & تُ \\
\hline & $\vec{D}^{N}$ & $\delta^{\circ}$ & & $\stackrel{\check{g}}{\dot{I}}$ & $\stackrel{\check{g}}{\dot{g}}$ & ¿ّ & تُ \\
\hline & $\sum^{\infty}$ & $b^{\circ}$ & & $\frac{4}{0}$ & $\stackrel{\widehat{\sigma}}{\grave{n}}$ & 守 & 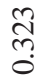 \\
\hline & $\begin{array}{l}0^{+} \\
\mathscr{W}^{1}\end{array}$ & $0^{\circ}$ & & $\stackrel{\check{I}}{=}$ & $\stackrel{\dot{I}}{\dot{g}}$ & $\stackrel{\check{I}}{\dot{I}}$ & $\stackrel{\vec{d}}{\dot{g}}$ \\
\hline & $\underset{\beth}{\beth}$ & $b^{0}$ & & $\stackrel{\vec{j}}{\vec{j}}$ & $\stackrel{\check{I}}{\text { d }}$ & $\ddot{d}$ & $\stackrel{\check{I}}{\dot{I}}$ \\
\hline & $\forall$ & $b^{\circ}$ & & $\begin{array}{l}\stackrel{\infty}{\infty} \\
\stackrel{0}{0}\end{array}$ & $\stackrel{+}{+}$ & $\stackrel{\widehat{\vartheta}}{\stackrel{?}{0}}$ & 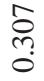 \\
\hline & $\begin{array}{l}\bar{\Xi} \\
\bar{Z}\end{array}$ & $\theta^{0}$ & & 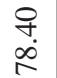 & $\begin{array}{l}\infty \\
m \\
\infty \\
\infty\end{array}$ & $\begin{array}{l}\stackrel{?}{+} \\
\stackrel{a}{a}\end{array}$ & ले \\
\hline \multicolumn{3}{|c|}{ 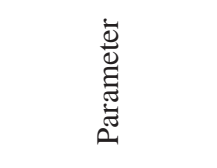 } & & 禀 & 㶵 & 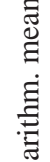 & 胥 \\
\hline \multicolumn{3}{|c|}{ 壳 } & \multicolumn{5}{|c|}{ 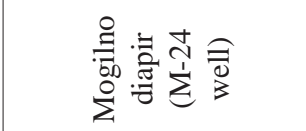 } \\
\hline
\end{tabular}

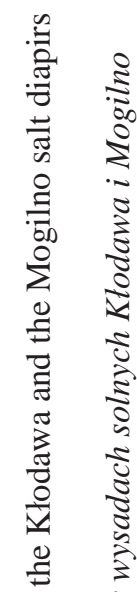

ㄷํ요 3

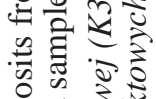

वें. กิ

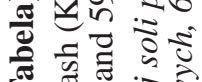

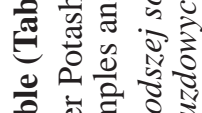

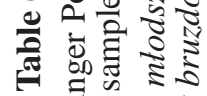

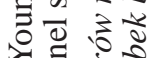

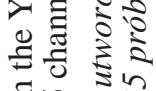
In 0 年 . 过

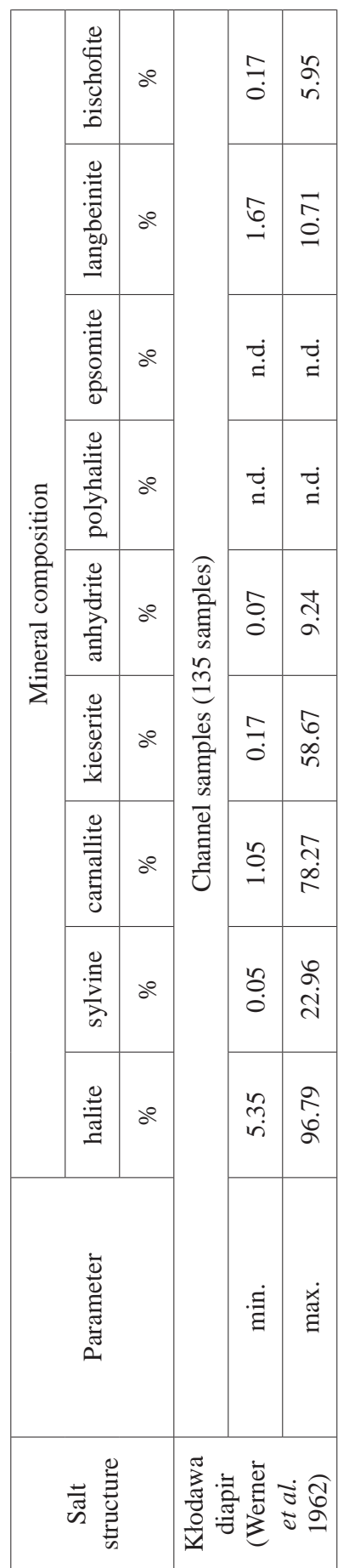




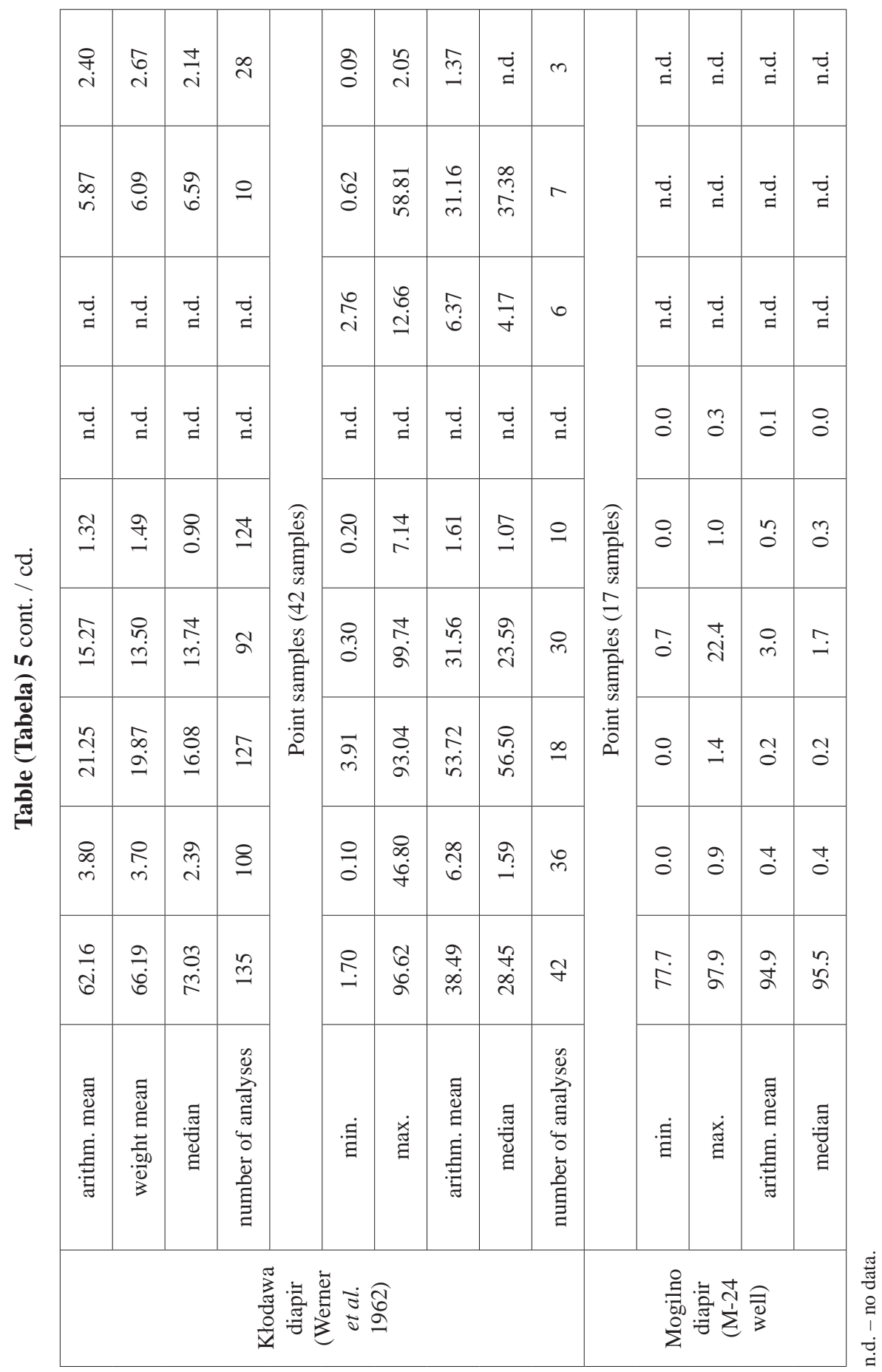


During the research project in 2005-2007 (Tomassi-Morawiec et al. 2008a, 2009) point samples (powder samples obtained by boring the rock) of K2 and K3 units were taken in selected sections in the Kłodawa Salt Mine. These samples were analyzed for the content of main components and trace elements.

Chemical analyses of the main salt rock components, carried out in the Salt Deposit and Chemical Raw Material Laboratory of the Department of Deposit and Mining Geology at the AGH University of Science and Technology in Krakow, entailed the determination of content:

- water-insoluble parts,

- $\mathrm{Cl}^{-}$ions by the argentometric method (Mohr's method),

- $\mathrm{K}^{+}, \mathrm{Mg}^{2+}, \mathrm{Ca}^{2+}$, and $\mathrm{S}^{2-}$ ions (converted later to $\mathrm{SO}_{4}{ }^{2-}$ ) by the ICP AES method.

The equipment errors were as follows: $\mathrm{S}-100 \mu \mathrm{g} / \mathrm{l}, \mathrm{K}-500 \mu \mathrm{g} / \mathrm{l}, \mathrm{Mg}-2 \mu \mathrm{g} / \mathrm{l}$, $\mathrm{Ca}-2 \mu \mathrm{g} / \mathrm{l}$. The error of the chlorine determination method was ca. $5 \%$, and that of the remaining ions: ca. $3 \%$.

Trace element analysis was conducted in the Central Chemical Laboratory of PGI-NRI. Determination of bromine, strontium, and rubidium in the samples prepared as powder tablets was carried out with X-ray fluorescence spectrometer (WD-XRF), model PW 2400 from Philips. The precision of this method, expressed by the relative error, is ca. 3\% (for Br content).

Determination results of the main components were converted to the mineral composition. Bromine content determined in the whole sample was converted to pure halite. For samples in which also other chlorides occurred (sylvine and/or carnallite), the weight relations of bromine in halite, sylvine and carnallite were assumed as follows: 1: 10: 7 (Braitsch \& Herrmann 1963). However, owing to the fact that literature also quoted other values of those proportions (Mattenklott, 1994), in the case of the samples with the increased sylvine $(>3.2 \%)$ and/or carnallite $(>0.4 \%)$ content, the calculated bromine content in halite was charged with the error exceeding 3\% (M. Schramm: oral communication). For the samples with low halite content $(<50 \%)$, the calculated bromine concentrations were very uncertain. That is why the calculation results obtained in such samples were not put in the statistics.

To make the mineral content of 11 samples more accurate, the additional analyses of the phase content were done with the X-ray diffraction (XRD) method, using a Philips X'Pert PW 3020 diffractometer.

For all the components, chemical and mineral, the basic statistical parameters were calculated (minimum, maximum and mean values: arithmetic mean and median) and listed in tables 6 and 7 (see interleaf).

\section{Determination of the chemical composition of salt samples from the Góra and Mogilno diapirs}

Determination of the chemical composition of the $\mathrm{K}-\mathrm{Mg}$ salt samples taken from the cores of M-24 and G-30 boreholes was conducted in 2006 at the Quality Control and Technology Department Laboratory of the Inowrocławskie Kopalnie Soli "Solino". The following ions content was determined: $\mathrm{K}_{\text {and }} \mathrm{SO}_{4}$ (weight method), $\mathrm{Ca}$ and $\mathrm{Mg}$ (complexometric method), and $\mathrm{Cl}$ (Mohr's method). 
Point samples from the G-39 borehole were taken in 2009 and they were analysed at the Technical University of Clausthal in Germany. Bromine and sulphate ion content was determined by the ion chromatography method. The accuracy of bromine content determination was $\pm 2 \mu \mathrm{g} \mathrm{Br} / \mathrm{g}$ of halite. Based on the sulphate ion content, the proportion of anhydrite in samples was calculated. Halite content is a supplement to $100 \%$ value. The determined bromine concentrations in the samples were converted into pure halite. Such a restricted analytical course (omitting determination of such ions as $\mathrm{Ca}^{2+}, \mathrm{K}^{+}, \mathrm{Mg}^{2+}$, and $\mathrm{Cl}^{-}$) does not allow to determine precisely the mineral composition of studied samples, and in the case of the samples collected from the units containing K-Mg salts, it could be expected that the determined bromine content was associated not only with halite, but also with other chlorides (sylvine, or carnallite).

The statistical parameters of determined chemical components and of the mineral components calculated on chemical data, referred to sampled formations in boreholes G-30 and M-24, were placed in tables 2-5.

\section{Determination of the chemical composition of salt samples from the Fore-Sudetic area (Zielona Góra and Rybaki locations)}

General geochemical characteristics of the Zechstein potash salts from the Fore-Sudetic area (Zielona Góra with the Nowa Sól environs and the so-called Rybaki structure) was based on the archival results of chemical analyses of salt samples (Podemski 1966, 1972b, Werner \& Dawidowski 1976) and on the published data (Podemski 1972a, 1973a, b, 1974a, b, 1975, Dawidowski 1976). The majority of chemical composition determinations was performed by the Central Laboratory of the Geological Institute (GLIG), and the analyzed material consisted mainly of channel samples, representing core sections with the length of $0.5-1.0 \mathrm{~m}$. In those samples, the content of following components was determined: water-insoluble parts, $\mathrm{K}, \mathrm{Na}, \mathrm{Mg}, \mathrm{Ca}, \mathrm{Cl}, \mathrm{SO}_{4}, \mathrm{Br}$, and $\mathrm{H}_{2} \mathrm{O}$. Based on the obtained data, the content of of the following compounds were calculated: $\mathrm{K}_{2} \mathrm{O}, \mathrm{NaCl}, \mathrm{CaSO}_{4}, \mathrm{MgSO}_{4}$, and the bromine to chlorine index value $\left(\mathrm{Br} \times 10^{3} / \mathrm{Cl}\right)$. From the Older Potash $(\mathrm{K} 2)$ seam from the Zielona Góra area, 157 samples taken from 17 boreholes were analyzed (Podemski 1966, 1972b), but only four samples from the Rybaki 14 borehole in the Rybaki structure (Podemski 1975). The Younger Potash (K3) seam from Zielona Góra area was represented by 12 samples taken from the Otyń IG-1 borehole (Podemski 1972a), while from the Rybaki structure 74 samples taken from three boreholes became analyzed (Podemski 1974b, Werner \& Dawidowski 1976).

\section{Petrological study methodology}

The petrological characteristics of potash-magnesium salts was based on analysis of archival materials collected in the Section of Salt Deposits and Chemical Raw Materials of the Department of Deposit and Mining Geology at the AGH University of Science and Technology in Krakow. The study concerned mainly on materials coming from the Kłodawa and the Inowrocław salt mines and included the results of underground mapping and the macroscopic 
samples descriptions done by the Section and by students during their graduation work. The macroscopic characteristics was supplemented later with the analysis of archival microscopic thin sections completed as part of graduation projects. 21 microscopic thin plates from $\mathrm{K} 2$ and 14 plates from K3 units at Kłodawa, and correspondingly 25 plates from K2 and 17 ones from K3 units at Inowrocław were studied.

\section{GEOLOGY AND GEOCHEMISTRY OF THE ZECHSTEIN POTASH UNITS}

\section{OLDER POTASH (K2) UNIT}

\section{Unit development in Central Poland}

\section{Studies in the Kłodawa Salt Mine}

The Older Potash (K2) unit in the Kłodawa and the Inowrocław diapirs has a similar development. It is represented by fine- to coarse-crystalline, white-greyish rock salt, changing to dark grey, dark-orange or grey-brownish, sometimes with honey colour. In the lower profile part the rock salt was thinly stratified with anhydrite (Charysz 1973), with anhydrite layers disappearing in the upper part, where ingrowths and thin overgrowths of potash-magnesium salts were appearing, mostly represented by kieserite, polyhalite, sylvine, and sometimes also by carnallite. Three types of K-Mg salts were identified (Hanczke 1969), after differing mineral proportions and development of particular components.

In the Kłodawa salt diapir the Older Potash (K2) unit created a complex (Werner et al. 1962) with a "stripped" texture (rhythmites), resulted from intermittent laminae and layers, $\mathrm{cm}-\mathrm{dcm}$ thick, of halite and halite+sylvine, often diversed in colours: white, cream, pink, brown, and grey, as well as from occurrence of thin layers of white kieserite and grey anhydrite, with accessory components as carnallite and polyhalite (Tomassi-Morawiec et al. 2008a, 2009). Moreover, langbeinite, gypsum, and clay minerals were found (Garlicki 1956, Hanczke 1969, Wachowiak 1992). The thickness of that complex varies from $6 \mathrm{~m}$ to $12 \mathrm{~m}$ (Chandij 1976). In the macroscopic image, the rocks are stratified, from several millimetres to ca. $2 \mathrm{~cm}$ thick and they clearly diverse in colours and mineral content. The layers composed of chloride minerals: white, transparent or light pink halite and colourless or pink to intensely red sylvine are dominating. Crystals size ranged from $1 \mathrm{~mm}$ to $5 \mathrm{~mm}$. Sulphate layers were mostly composed of white kieserite or dark grey anhydrite, accompanied by small-crystalline halite, and locally polyhalite as well. Numerous carnallite veins, generated by tectonic deformations (Wachowiak 1992) are observed within these deposits.

Described unit was developed as kieserite-carnallite association in its lower part, and as a hard kieserite-anhydrite-polyhalite salt in its upper part. Within the south-western anticline of the diapir, this unit was built of beige-pink, equal-crystalline, corese-crystalline laminated salt. In the lower part of the profile, close to the contact with the Older Halite (Na2) unit, this unit contained more kieserite and carnallite (Tomassi-Morawiec et al. 2008a, 2009), while in 
the upper section it displayed the features of "a hard salt", with the dominated anhydrite and polyhalite. Distances between the sulphate-clay laminae are 20-25 $\mathrm{mm}$, and they are comparable with those observed in the neighbouring "transitional series" $(\mathrm{Na} 2+\mathrm{K} 2)$ (Werner et al. 1960, Hanczke 1969, Charysz 1973).

The Older Potash unit, within the north-eastern marginal anticline of the diapir, at the level of $600 \mathrm{~m}$, was tectonically wedged within the Older Halite unit (Burliga et al. 2004). Salts of that series were locally devoid of lamination, textureless, polymorphic and coarse-crystalline, grey-bluish, with porphyrythic structure: the matrix consists of halite crystals, while the porphyre crystals are mainly represented by polyhalite. Also anhydrite debris was found, with the diameter of 5-6 cm and as well as the fragments of blue halite crystals, produced by cataclastic disrupition of sulphate and blue halite layers (Burliga et al. 2004). In the upper part of the unit are frequent lenses, flames and dispersed aggregates of secondary polyhalite.

Regular lamination in the potash salt profile suggested its development in conditions of relatively deep salinas, with rhythmic repetition of condensation and stratification of brine, without considerable leaching of accumulated deposit as a result of brine dissolution or the bottom emersion.

\section{Studies in the Inowrocław salt diapir}

The Older Potash unit was slightly differently formed in the Inowrocław salt diapir. Together with the "hard" anhydrite-kieserite salts with admixture of polyhalite there occurred also the kieseritic carnallitite (Charysz 1973, Satanowski 1973, Bednarz \& Pasierb 1974, Stańczyk-Stasik 1976). Macroscopically and microscopically, the "hard" salts were similar as those in the Kłodawa diapir.

Kieseritic carnallitite is a fine- to coarse-crystalline rock, with colours varied from red or cherry to pink to white. It is stratified with thin kieserite and rock salt interbeds and contained nests of grey clay and anhydrite. Carnallite is mostly red, cherry, and sometimes yellow, with crystal sizes from $1 \mathrm{~mm}$ to $5 \mathrm{~mm}$. Halite, colourless or light honey in colour, accompanied carnallite and that one as separate thin layers is usually larger up to $10 \mathrm{~mm}$. It was often accompanied by small clay or anhydrite aggregates.

\section{Geochemical characteristics}

\section{Data analysis of the archive geological documentation of the potash-magnesium salt deposit in the Klodawa diapir (Werner et al. 1962)}

The archive results of chemical analyses from salt cores, representing K2 unit in the boreholes drilled the Kłodawa diapir for documentation purposes (Werner et al. 1962), concerned 100 channel samples and 11 point ones (Tab. 1). These results were converted to basic sulphate and chloride groups occurred in salt formations, followed by mineral content calculations. In 31 channel samples from borehole K32 the bromine content was also determined. Statistical parameters of the determined and calculated chemical and mineral components were presented in tables 2 and 3. 
Table (Tabela) 6

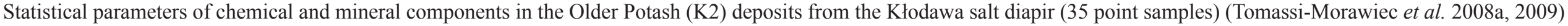

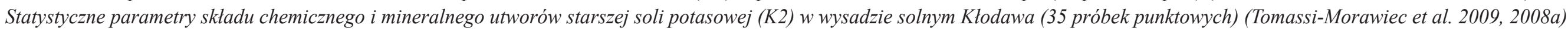

\begin{tabular}{|c|c|c|c|c|c|c|c|c|c|c|c|c|c|c|c|c|c|c|}
\hline \multirow{3}{*}{ Parameter } & \multicolumn{11}{|c|}{ Chemical composition } & \multicolumn{7}{|c|}{ Mineral composition } \\
\hline & $\mathrm{Na}$ & $\mathrm{K}$ & $\mathrm{Mg}$ & $\mathrm{Ca}$ & $\mathrm{Cl}$ & $\mathrm{SO}_{4}$ & $\begin{array}{l}\text { inso- } \\
\text { lubles }\end{array}$ & $\mathrm{Sr}$ & $\mathrm{Rb}$ & $\mathrm{Br}$ & $\begin{array}{l}\text { Brin } \\
\text { halite }\end{array}$ & halite & sylvine & $\begin{array}{c}\text { carnal- } \\
\text { lite }\end{array}$ & $\begin{array}{l}\text { anhy- } \\
\text { drite }\end{array}$ & kieserite & $\begin{array}{l}\text { polyha- } \\
\text { lite }\end{array}$ & $\begin{array}{c}\text { langbei } \\
\text { nite }\end{array}$ \\
\hline & $\%$ & $\%$ & $\%$ & $\%$ & $\%$ & $\%$ & $\%$ & ppm & ppm & ppm & ppm & $\%$ & $\%$ & $\%$ & $\%$ & $\%$ & $\%$ & $\%$ \\
\hline $\min$. & 3.29 & 0.29 & 0.04 & 0.03 & 6.55 & 0.96 & 0.01 & 10 & $<3$ & 14 & 95 & 8.4 & 0.0 & 0.0 & 0.0 & 0.0 & 0.0 & 0.0 \\
\hline $\max$. & 38.23 & 29.77 & 8.24 & 11.11 & 59.53 & 51.99 & 12.72 & 553 & 32 & 974 & 329 & 97.2 & 56.5 & 22.1 & 14.3 & 52.2 & 18.0 & 20.0 \\
\hline arithm. mean & 23.37 & 8.56 & 2.28 & 1.53 & 42.75 & 14.93 & 1.60 & 160 & 12 & 390 & 180 & 58.1 & 14.3 & 1.9 & 2.4 & 12.7 & 2.0 & 2.9 \\
\hline median & 25.18 & 6.92 & 1.35 & 0.57 & 46.53 & 12.61 & 0.92 & 75 & 11 & 320 & 162 & 64.0 & 11.0 & 0.0 & 0.3 & 10.0 & 1.2 & 0.0 \\
\hline number of analyses & 35 & 35 & 35 & 35 & 35 & 35 & 35 & 35 & 35 & 35 & 23 & 35 & 35 & 35 & 35 & 35 & 35 & 35 \\
\hline
\end{tabular}

\section{Table (Tabela) 7}

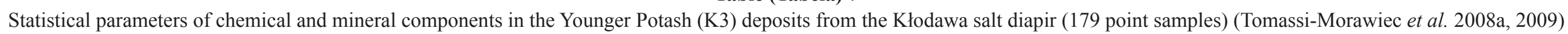

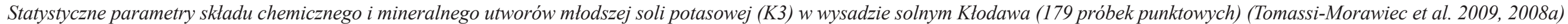

\begin{tabular}{|c|c|c|c|c|c|c|c|c|c|c|c|c|c|c|c|c|c|c|}
\hline \multirow{3}{*}{ Parameter } & \multicolumn{11}{|c|}{ Chemical composition } & \multicolumn{7}{|c|}{ Mineral composition } \\
\hline & $\mathrm{Na}$ & $\mathrm{K}$ & $\mathrm{Mg}$ & $\mathrm{Ca}$ & $\mathrm{Cl}$ & $\mathrm{SO}_{4}$ & $\begin{array}{l}\text { inso- } \\
\text { lubles }\end{array}$ & $\mathrm{Sr}$ & $\mathrm{Rb}$ & $\mathrm{Br}$ & $\begin{array}{l}\mathrm{Br} \text { in } \\
\text { halite }\end{array}$ & halite & sylvine & $\begin{array}{c}\text { carnal- } \\
\text { lite }\end{array}$ & $\begin{array}{l}\text { anhy- } \\
\text { drite }\end{array}$ & kieserite & $\begin{array}{l}\text { polyha- } \\
\text { lite }\end{array}$ & $\begin{array}{l}\text { langbei- } \\
\text { nite }\end{array}$ \\
\hline & $\%$ & $\%$ & $\%$ & $\%$ & $\%$ & $\%$ & $\%$ & ppm & ppm & ppm & $\mathrm{ppm}$ & $\%$ & $\%$ & $\%$ & $\%$ & $\%$ & $\%$ & $\%$ \\
\hline $\min$. & 0.00 & 0.06 & 0.03 & 0.00 & 2.84 & 0.03 & 0.00 & $<3$ & $<3$ & 70 & 125 & 0.0 & 0.0 & 0.0 & 0.0 & 0.0 & 0.0 & 0.0 \\
\hline $\max$. & 39.98 & 12.70 & 12.09 & 4.40 & 60.39 & 47.50 & 36.22 & 1016 & 86 & 2253 & 502 & 99.1 & 9.2 & 90.3 & 14.9 & 62.5 & 11.0 & 3.4 \\
\hline arithm. mean & 32.01 & 1.71 & 1.46 & 0.49 & 54.07 & 2.77 & 0.81 & 95 & 16 & 466 & 262 & 81.4 & 0.3 & 10.9 & 1.5 & 2.4 & 0.1 & 0.0 \\
\hline median & 35.5 & 0.57 & 0.45 & 0.25 & 56.91 & 1.07 & 0.10 & 39 & 10 & 330 & 257 & 90.3 & 0.1 & 3.3 & 0.8 & 0.0 & 0.0 & 0.0 \\
\hline number of analyses & 179 & 179 & 179 & 179 & 179 & 179 & 179 & 179 & 179 & 179 & 158 & 179 & 179 & 179 & 179 & 179 & 179 & 179 \\
\hline
\end{tabular}


Channel samples. Halite content in the channel samples varies from $20.16 \%$ to $98.17 \%$ (weighted mean: 78.57\%). In 93 samples the anhydrite accompanied halite in the quantity from $0.07 \%$ to $11.90 \%$. Sylvine was quite common in the examined material. Its content varies from $0.08 \%$ to $62.50 \%$ (weighted mean: $8.05 \%$ ). In half of the examined set of samples, the sylvine content exceeded $4.22 \%$ (median value). Calculations of mineral composition indicated the presence of carnallite in 61 samples. Its content is highly varied, $0.12-23.78 \%$ (weighted mean: $2.65 \%$ ). The studied core material of Older Potash unit also contained magnesium sulphates: kieserite (in 42 samples, its content was from $0.11 \%$ to $22.52 \%$; weighted mean: $4.17 \%$ ) and epsomite (in 18 samples, its content ranged from $0.49 \%$ to $21.40 \%$; weighted mean: $5.15 \%$ ). Also polyhalite was determined in 19 channel samples, in the quantity from $1.08 \%$ to $15.23 \%$ (weighted mean: $5.70 \%$ ), and in 32 samples the langbeinite was detected in the quantity from $0.43 \%$ to $11.55 \%$ (weighted mean: $3.91 \%$ ). The content of water-insolubles varies from $0.01 \%$ to $44.68 \%$. Bromine concentrations were determined in the samples from borehole K-32. They were high, ranging from $160 \mathrm{ppm}$ to $1050 \mathrm{ppm}$, with the weighted mean of $440 \mathrm{ppm}$. Such a high bromine content indicated that the element was associated not only with halite, but also with sylvine and carnallite.

Point samples. All of the 11 analyzed samples were taken from K-52 borehole. Some analyses (especially determinations of potash and magnesium content) were done with other analytical methods than was applied for the channel samples. The content ranges of main chemical compounds: sodium chloride, potash chloride, and calcium sulphate were different from those of channel samples, and the mean content values were usually lower in comparison to those ones from channel samples. Halite content in the analyzed 11 samples vaies from $50.23 \%$ to $93.84 \%$, for sylvine: from $0.36 \%$ to $7.15 \%$; for anhydrite: from $0.61 \%$ to $2.98 \%$, and for insoluble parts: from $0.22 \%$ to $10.57 \%$. In both types of samples, the content of magnesium sulphate and polyhalite (average content value are diverse) are similar (Tabs 2,3).

Fig. 2. Schematic geological cross-section of the Kłodawa salt diapir (after Burliga 1997), with the position of the lithological-geochemical profile (fragment) of Older Potash (K2) deposits in the Kłodawa mine gallery at level - $600 \mathrm{~m}$ (Tomassi-Morawiec et al. 2008a). Explanations: Q - Upper Neogene (Pleistocene-Holocene), Tr - Paleogene and Lower Neogene (Miocene-Pliocene), J3 - Upper Jurassic, J2 - Middle Jurassic, J1 - Lower Jurassic, T - Triassic; Zechstein lithostratigraphic units: Na4t - Red Zuber, Na4a - Youngest Halite, Na3t - Brownish Zuber, Na 3b - Upper Younger Halite, K3 - Younger Potash, Na3a - Lower Younger Halite, A3 - Main Anhydrite, T3+Ca3 - Grey Pelite + Platy Dolomite, A2r - Screening Anhydrite, Na2r - Screening Older Halite, K2 - Older Potash, Na2 - Older Halite, Na1 - Oldest Halite; p.k. - mining level

Fig. 2. Schematyczny przekrój geologiczny przez wysad solny Kłodawa (wg Burliga 1997) i fragment profilu litologiczno-geochemicznego utworów ogniwa starszej soli potasowej (K2) w wyrobisku kopalni na poziomie -600 m (Tomassi-Morawiec et al. 2008a). Objaśnienia: Q - górny neogen (plejstocen-holocen), $\mathrm{Tr}$ - paleogen i dolny neogen (miocen-pliocen), J3 - górna jura, J2 - środkowa jura, $\mathrm{J} 1$ - dolna jura, T - trias; wydzielenia litostratygraficzne cechsztynu: Na4t - zuber czerwony, Na4a najmłodsza sól kamienna, Na3t - zuber brunatny, Na3b - młodsza sól kamienna górna, K3 - młodsza sól potasowa, Na3a - młodsza sól kamienna dolna, A3 - anhydryt główny, T3+Ca3 - szary ił solny + dolomit płytowy, A2r - anhydryt kryjący, Na2r - starsza sól kamienna kryjąca, K2 - starsza sól potasowa, $\mathrm{Na} 2$ - starsza sól kamienna, Na1 - najstarsza sól kamienna; p.k. - poziom kopalniany 


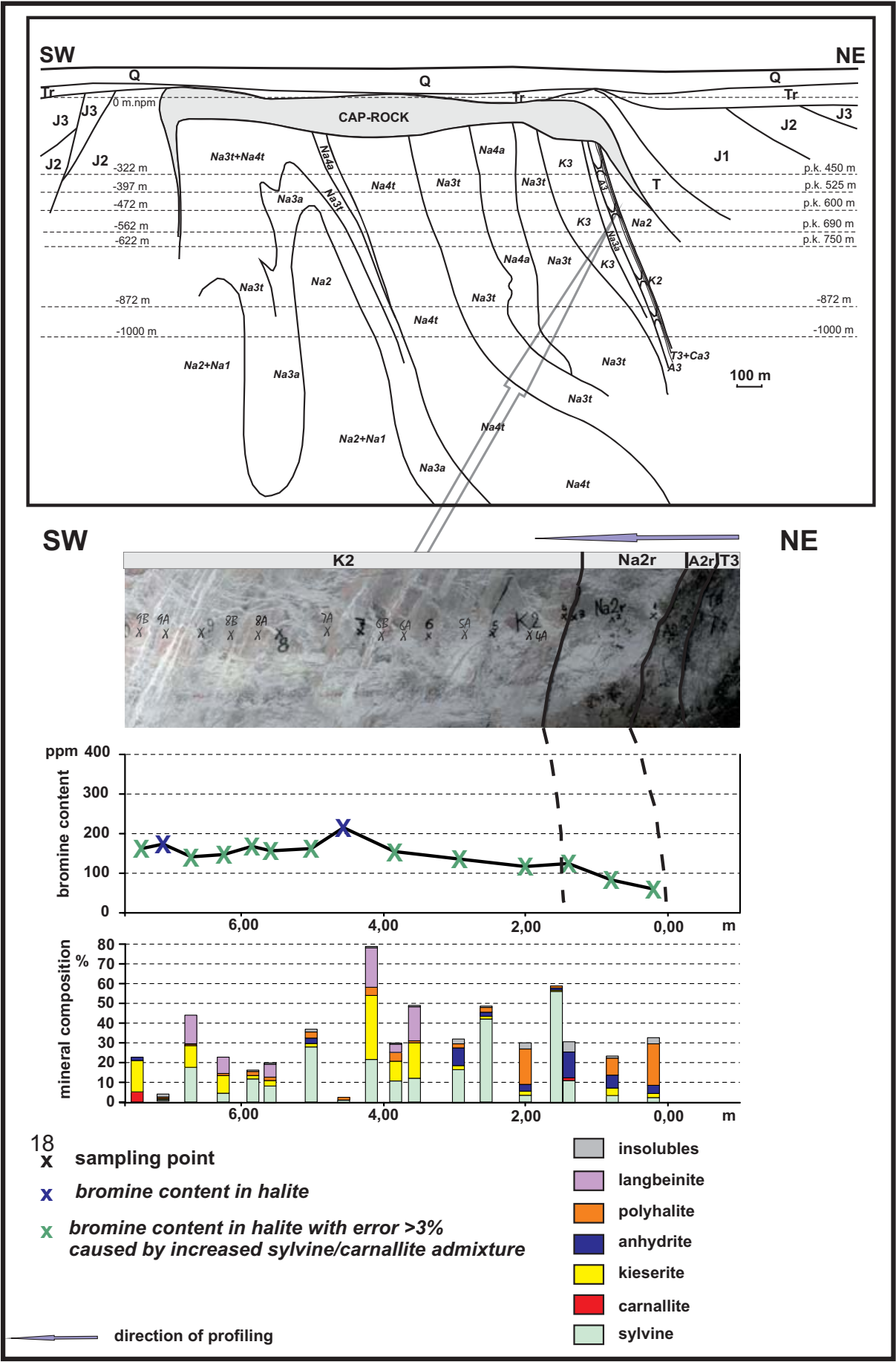




\section{Results of the research project performed in the Klodawa diapir in 2005-2007 (Tomassi-Morawiec et al. 2008a, 2009)}

A number of point samples were taken from three sections seleceted in the Kłodawa salt mine, entailing lithostratigraphic units of cyclothem PZ2. The Older Potash (K2) unit is represented by 35 samples. Statistical parameters of the determined chemical components and calculated mineral components are placed in table 6. A fragment of the panorama of one of the studied profiles, with the bromine and the mineral content values identified in the samples is presented in figure 2 .

The average halite content the following in the examined set of samples was $58.1 \%$. Salt rocks representing the K2 unit characterized with high concentrations of potash and magnesium, reaching $29.77 \%(\mathrm{~K})$ and $8.24 \%(\mathrm{Mg})$, with the average content of those elements of $8.56 \%$ and $2.28 \%$, respectively, and a relatively high average sulphate ion concentration: $14.93 \%$. Proportion of insoluble parts (0.01-12.72\%) was close to that one found in the set of samples collected from K-52 borehole. In the majority of tested samples anhydrite $(0-14.3 \%)$ and kieserite $(0-52.2 \%)$ were found. The rock enriched with kieserite was often presented in the form of numerous white laminae interbedded with the layers depleted in that mineral.

Also a large content of other chlorides (except halite), especially sylvine, was observed in the studied rocks. The sylvine content changed from $0 \%$ to $56.5 \%$ (with the average of $14.3 \%$ ), and that of carnallite from $0 \%$ to $22.1 \%$ (with the average of $1.9 \%$ ). In half of analyzed samples set the sylvine content exceeded $11.0 \%$ (median value). Polyhalite $(0-18 \%)$ was fairly common in the tested samples, and langbeinite occurred less often (0-20\%).

In the majority of samples representing the Older Potash unit, high bromine concentrations were found, varied from 14 ppm to 974 ppm, with the mean content of $390 \mathrm{ppm}$. The determined bromine concentrations were associated not only with halite, but also with sylvine and carnallite. A high proportion of those chlorides in studied rocks did not allow to determine precisely the bromine content in halites.

The strontium content in tested samples varies from $10 \mathrm{ppm}$ to $553 \mathrm{ppm}$. That element was associated with calcium and its highest concentrations were observed in the samples with high anhydrite or polyhalite content. The rubidium content ranged from $<3 \mathrm{ppm}$ to $32 \mathrm{ppm}$, but its highest values were found in the samples with increased proportions of sylvine and langbeinite.

\section{Data analysis from the selected boreholes in the Góra and the Mogilno salt diapirs}

The discussed unit occurred only in the profiles of boreholes G-30 and M-24 as concentrations and layers of $\mathrm{K}-\mathrm{Mg}$ salt, within the grey to beige rock salt.

In tables 2 and 3 were include the statistical parameters of determined chemical components and calculated on that basis mineral components (for 14 channel samples from G-30 borehole and for four point samples from M-24 borehole). The sodium chloride content was variable in the tested rocks, and it ranged from ca. $80.0 \%$ to ca. $98.0 \%$ in the core from G-30 
borehole and from ca. $84.0 \%$ to ca. $96.0 \%$ in M-24 borehole. The mean halite content in the samples from both boreholes was: $89.7 \%$ (G-30) and 91.9\% (M-24), respectively. Calcium sulphate (anhydrite) is a subordinate component and its content ranged from $0 \%$ to ca. $4 \%$ $(<0.5 \%$ in the majority of samples). The magnesium content in the channel samples varies from $0.061 \%$ to $2.076 \%$, and for point samples $-0.252-2.968 \%$. Mean magnesium concentration in samples from the Góra diapir was $0.749 \%$. The potash content did not exceed $0.5 \%$, and its ranges were $0.152-0.479 \%$ (G-30) and 0.136-0,454\% (M-24). Mean potash content in both types of samples was ca. $0.35 \%$. Rocks representing the Older Potash units in both diapirs were rich in kieserite and its content ranged from $<0.5 \%$ to about a dozen of percent: $11.8 \%$ (G-30) and $16.8 \%$ (M-24). The presence of other sulphates was limited; polyhalite or langbeinite content reached locally ca. $2 \%$. The tested rocks were poor in sylvine; its content usually did not exceed $0.5 \%$. Carnallite occurred locally in the quantities reaching several percent in samples from G-30 borehole.

\section{Comments on geochemical results}

Diverse methodologies of testing the samples from the Older Potash unit in the Kujawy Region, applied in various periods by various geochemists (various sampling methods, various analytical and calculations methods) made it difficult to both compare the research results or drawing the conclusions. Based on the above quoted detailed test results (it should be noticed that the study material from Kłodawa salt diapir was much larger), it was attempted a fairly general geochemical and mineralogical characteristics of discussed unit, as well as specification of main differences in the chemical and mineral compositions of it found in Kłodawa, Góra, and Mogilno salt diapirs:

- halite content found in sections sampled in the Kłodawa Salt Mine was much more diverse than that found in profiles of other two diapirs;

- the material from Kłodawa diapir was characterized by a much higher potash and magnesium contents comparing to this one from Góra and Mogilno diapirs;

- anhydrite and kieserite were common in the tested rocks; however, they were on average less common in samples from Góra and Mogilno than in those from the Kłodawa diapir;

- the Older Potash unit from the Kłodawa diapir was rich in sylvine, while carnallite was less common; analogous rocks from other two diapirs were poor in sylvine, with the mean content of carnallite being similar to that of the Kłodawa diapir;

- polyhalite was a quite common mineral, but langbeinite occurred quite seldom in the tested rocks;

- bromine content in the Older Potash unit of the Kłodawa diapir was very high in the majority of samples.

\section{Literature data from wells drilled in the Fore-Sudetic Monocline area}

The Older Potash (K2) seam was identified by 90 boreholes located from the state border to Sulechów and Nowa Sól areas at the depth of ca. $917 \mathrm{~m}$ in the Nowa Sól to ca. 1510-1880 m at Rybaki and west of Krosno Odrzańskie. Seam thickness changed 
from $0 \mathrm{~m}$ to $20 \mathrm{~m}$, with the maximum of $30 \mathrm{~m}$ (Czapowski \& Bukowski 2009). In the Zielona Góra area (with 17 boreholes) this bed is from $3.5 \mathrm{~m}$ to $22.5 \mathrm{~m}$ thick (K2p; Podemski 1972a, 1973a, b, 1974a, b, 1975) and it was composed of interbedding layers, dcm to $1 \mathrm{~m}$ thick, representing the following mineral associations: halite + sylvine, halite + anhydrite + polyhalite, and rarely kieserite, with the domination of polyhalite in the seam top and the bottom. Mean content of $\mathrm{K}_{2} \mathrm{O}$ amounted to $1-9 \%$ (4-9\% in rich sections), with maximum value $25 \%$.

In the Rybaki area (Podemski 1972a, b, 1973a, b, 1974a, b, 1975), this unit, 3.5-26 m thick, occurs at the depth of ca. 1510-1870 m and was strongly tectonically affected. It was composed of interbedding thin and thicker layers of rock salt, rock salt with sylvine, and a hard polyhalite-anhydrite potash salt. Generally, they are secondary salts after the primary carnallite ones.

Analysis of chemical composition of 157 samples taken from core material of 17 boreholes in the Zielona Góra area (Podemski 1972b, 1973a, b, 1974a, b) indicated the following content values of main components of the Older Potash unit: $\mathrm{K}_{2} \mathrm{O}$ - from $1 \%$ to $15 \%$, sulphates - from $0.5 \%$ to $28 \%$ (mean: $5-15 \%$ ); $\mathrm{NaCl}$ - from $60 \%$ to $95 \%$ (mostly: $85-95 \%$ ), with $\mathrm{Br} / \mathrm{Cl}$ index in the range of $0.22-0.46$ (Fig. 3).

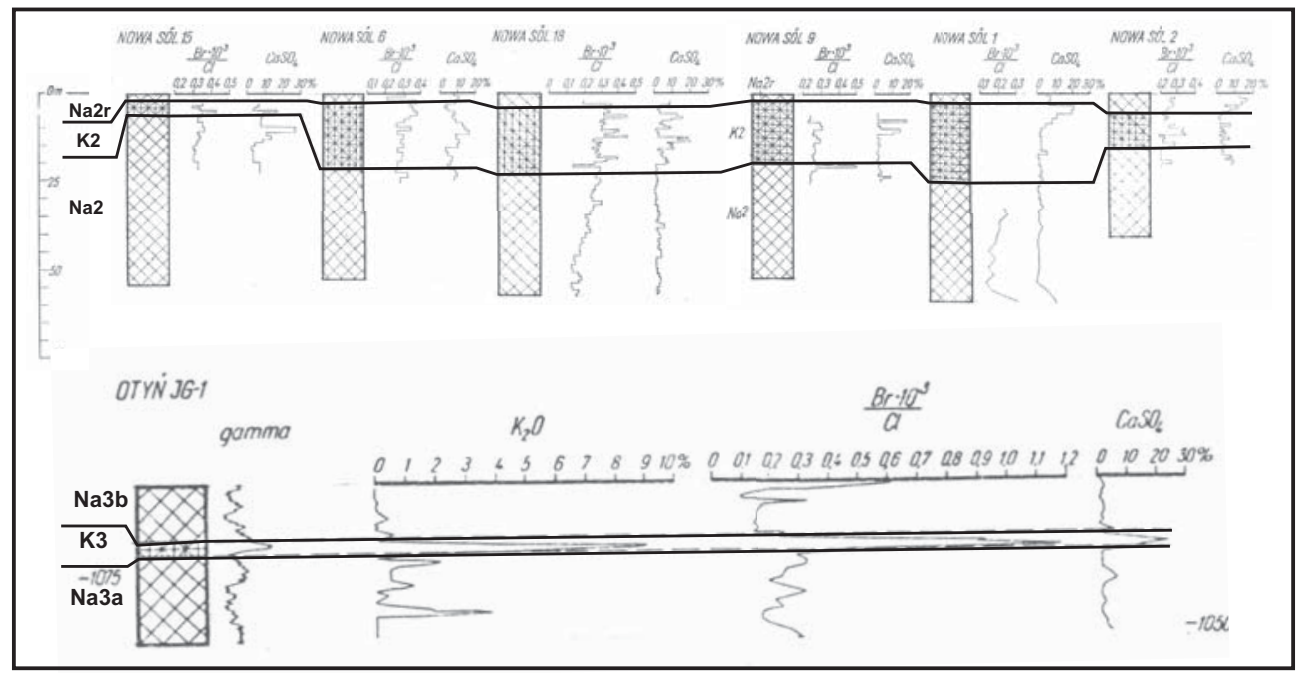

Fig. 3. Synthetic geochemical profiles of the Older Potash (K2) and the Younger Potash (K3) units in the boreholes of Nowa Sól, Fore-Sudetic area (Podemski 1972a). Same explanations as in figure 2

Fig. 3. Syntetyczne profile geochemiczne utworów starszej (K2) i młodszej (K3) soli potasowej w otworach wiertniczych z rejonu Nowej Soli na obszarze przedsudeckim (wg Podemski 1972a). Objaśnienia jak na figurze 2

The $\mathrm{K}_{2} \mathrm{O}$ content in four channel samples from Rybaki 14 borehole (Podemski 1975) ranged from $9 \%$ to $18 \%$. 


\title{
YOUNGER POTASH (K3) UNIT
}

\section{Unit development in Central Poland}

\author{
Studies in the Klodawa Salt Mine
}

In the studied profiles from the Kłodawa Salt Mine (Tomassi-Morawiec et al. 2008a, 2009), that unit was 20-35 m thick but tectonic repetitions and vaied layers strike caused the observed thickness reached $135-173 \mathrm{~m}$.

The unit is composed of beds set, 20-35 m thick (Chandij 1976), included three fine, white to cream to bright or dark grey up to various red hues in colour (Fig. 6F) kieseritecarnallite seams, with thin layers of white kieserite Theses semes were serparated by two rock salt beds.

Close to the NE marginal anticline, at the level of $600 \mathrm{~m}$, this unit created a core of adjacent syncline. There occurs the $42 \mathrm{~m}$ thick series of grey and pink equi- to polycrystalline rock salt, rhythmically laminated with anhydrite fine aggregates, with admixture or dispersed (flames) carnallite, kieserite, sylvine, and the veins of secondary giant salt (TomassiMorawiec et al. 2008a, 2009). Anhydrite-clay laminae, 1-5 cm thick, occurred 3-12 cm apart. The upper part of the $\mathrm{K} 3$ unit profile was composed of grey and pink equi- to polycrystalline rock salt, usually coarse-crystalline, textureless, with carnallite and clay matter either dispersed or as aggregates and flames.

In both salt types: stratified and textureless were observed the veins of red-white kieserite-carnallite and pure carnallite of various size.Within those veins, authomorphic crystals of secondary anhydrite and crystal salt were found. The folded zone within K3 unit had the apparent thickness from $50 \mathrm{~m}$ to more than $65 \mathrm{~m}$, in which occurred the polycrystalline rock salt, with clay admixture and tectonically transformed halite crystals, often rhythmically interbedded with the carnallite-halite layers. Such rhythmic layering became intensely tectonically disturbed, creating several complex folded and disjunctive structures (Burliga et al. 1995, 2004, Burliga 1997).

In rocks of the Younger Potash unit (Hanczke 1969) various proportions of halite, carnallite, kieserite, sylvine, and anhydrite were identified, and less often boracite, polyhalite, bischofite, epsomite, langbeinite, quartz, and illite.

In the upper part of the $\mathrm{K} 3$ unit, the systems of drying cracks are visible (Tomassi-Morawiec et al. 2008a, 2009), also described as polygonal structures (Poborska-Młynarska 1984, Garlicki 1987, Tarka 1989, Burliga 1995). The cracks were 15-30 cm wide, 0.3-1.5 m long and filled with clay and polycrystalline halite. The crack tops were cut by clay layer up to $1 \mathrm{~cm}$ thick, defining the emersed surface of basin bottom.

Textural similarity of the potash salt series with the surrounding Younger Halite (Na3) rocks suggests that the sedimentary conditions of both salt units were similar. Potash salts were formed in a fairly deep salina, with regularly renewed, highly concentrated brines favouring K-Mg chloride precipitation (Czapowski 1994). Finally, the basin was dried sporadically and dessication cracks became formed in the emerged bottom deposit. 


\section{Studies in the Góra and Mogilno salt diapirs}

The discussed unit, identified in the profile of G-39 borehole from the Gora salt diapir (Fig. 5), is composed of beige and transparent, coarse-crystalline salts, with packets of potash-magnesium salts (whose composition was hard to determine owing to strong core weathering). The potash-magnesium salt packets were rhythmically stratified with rock salt layers 1-2 cm thick. Anhydrite and clay matter appeared as admixtures. In the higher part of the unit, systems of 5-10 cm high vertical cracks were observed. They were filled with halite with potash salt and clay, quite analaogous to the drying cracks, recorded in similar stratigraphic position in profiles from the Kłodawa mine.

In the Mogilno diapir the Younger Potash unit was defiend only in the profile of borehole M-24. It consists of rock salt, with grey to honey to brownish colours, with a small admixture of clay matter and anhydrite aggregates. This salt contains a quite considerable amount of kieserite and a number of $\mathrm{K}-\mathrm{Mg}$ salts cocentartions and layers.

\section{Geochemical characteristics}

\section{Data analysis of the archive geological documentation of the potash-magnesium salt deposit in the Kłodawa diapir (Werner et al. 1962)}

The archive results of chemical analyses of the salt cores representing the K3 unit (Werner et al. 1962) refer to 135 channel samples and 42 point ones (Tab. 1). These results were converted into basic sulphate and chloride groups which occurred in the salt deposits, followed by calculation to mineral components. In 80 channel samples from boreholes K24 and K25, also bromine content was determined. Statistical parameters and the converted chemical and mineral components were placed in tables 4 and 5 .

Channel samples. Halite content in the channel samples ranged from 5.35\% to $96.79 \%$ (arithmetic mean: 62.16\%, weighted mean: 66.19\%). Anhydrite was found in 124 samples, accompanied halite in the quantity from $0.07 \%$ to $9.24 \%$. Sylvine and carnallite were common in the tested samples, with sylvine content ranging from $0.05 \%$ to $22.96 \%$ (weighted mean: $3.70 \%$ ) and carnallite (found in 127 samples) content from $1.05 \%$ to $78.27 \%$ (weighted mean: $19.87 \%$ ). In half of tested samples set the carnallite content exceeded $16 \%$ (median value). In 28 channel samples also bischofite was determined (17-5.95\%). In addition to anhydrite other sulphates were determined: fairly common kieserite - in 92 samples, its content ranged from $0.17 \%$ to $58.67 \%$ (weighted mean: $13.50 \%$ ), and fairly rare langbeinite - in ten samples, ranging from $1.67 \%$ to $10.71 \%$.

Point samples. In the set of point samples was observed a similar halite content variability (1.70-96.62\%), although its mean content was much lower than in the channel samples: $38.49 \%$. In the large majority of samples, sylvine was identified. Its concentrations ranged from $0.10 \%$ to $46.80 \%$ (mean: $6.28 \%$ ). Carnallite content calculated for 18 samples was high and changing from $3.91 \%$ to $93.04 \%$. In three samples, bischofite was identified, with maximum content of $2.05 \%$. Kieserite was fairly common in the tested samples and its 
concentrations were ranging from $0.30 \%$ to $99.74 \%$ (mean: $31.56 \%$ ) in 30 samples. In addition, anhydrite content was calculated in ten samples $(0.20-7.14 \%)$, epsomite in six samples (2.76-12.66\%) and langbeinite (0.62-58.81\%) in seven samples.

\section{Results of the research project performed in the Klodawa diapir in 2005-2007 (Tomassi-Morawiec et al. 2008a, 2009)}

Many point samples were taken from two profiles from the Kłodawa Salt Mine, entailing lithostratigraphic salt units of the PZ3 cyclothem. 179 samples were collected from the K3 unit. Statistical parameters determining chemical components and calculated mineral components are presented in table 7. A fragment of the panorama of one of the examined profiles, with the bromine and mineral content data visible on figure 4.

In the Younger Potash (K3) unit, the sodium and chlorine content was very diverse indicating that some samples did not contain halite at all, or it amounted to several percent only. Mean halite content was $81.4 \%$. The maximum content of potash and magnesium was ca. $12 \%$. Mean content of sulphate ion in the Younger Potash unit was lower (2.77\%) than in of the Older Potash one, which indicated a lower proportion of sulphates therein. Mean calcium content was $0.49 \%$. In several samples taken from carnallite-kieserite layers, very high concentrations of insolubles (reaching $36.22 \%$ ) were found, which was probably associated with incomplete dissolution of sulphates (kieserite, polyhalite, and langbeinite) during the analyse, constituting a large admixture in those samples.

Anhydrite and carnallite were common in the tested rocks. The maximum anhydrite content reached $14.9 \%$, and its mean concentration was $1.5 \%$. In half of the samples set the anhydrite content was below $0.8 \%$ (median value in both profiles). Mean concentrations of carnallite in the Younger Potash unit - 10.90\% - was higher than in case of the Older Potash one. The maximum determined carnallite content of $90.3 \%$ was associated with the kieserite-carnallite layers. Kieserite occurred irregularly and usually in small quantities, its mean content amounted to $2.40 \%$ but nn the majority of samples it did not exceed $1 \%$. Larger concentrations of that mineral (reaching 62.5\%) were determined in the kieserite-carnallite layers, as well as in their vicinity. Sylvine was quite uniformly dispersed in small quantities in the tested rocks. Its content ranged from $0 \%$ to $9.2 \%$, with mean $0.3 \%$. Sylvine concentrations exceeding $0.5 \%$ occurred only in about a dozen of samples. In one sample, taken from a kieserite-carnallite layer, the volume of polyhalite (11.0\%) and langbeinite (3.4\%) was identified.

Determined bromine concentrations in the majority of samples were very varied, from $70 \mathrm{ppm}$ to $2253 \mathrm{ppm}$. The calculated mean bromine content in halite (charged with the error exceeding $3 \%$ ) was $262 \mathrm{ppm}$.

Strontium content in the tested rocks ranged from $<3 \mathrm{ppm}$ to $1016 \mathrm{ppm}$, and that of rubidium from $<3$ ppm to $86 \mathrm{ppm}$.

Comparative studies of trace element contents in various types of evaporates from the Polish territory, conducted late in the 1980's (Garlicki et al. 1991) identified the quantities of the following elements in the Younger Halite unit of the Kłodawa Salt Mine: rubidium from $40.9 \mathrm{ppm}$ to $5,915 \mathrm{ppm}$, bromine from $110 \mathrm{ppm}$ to 4,500 ppm, and mean 1,500 ppm. 


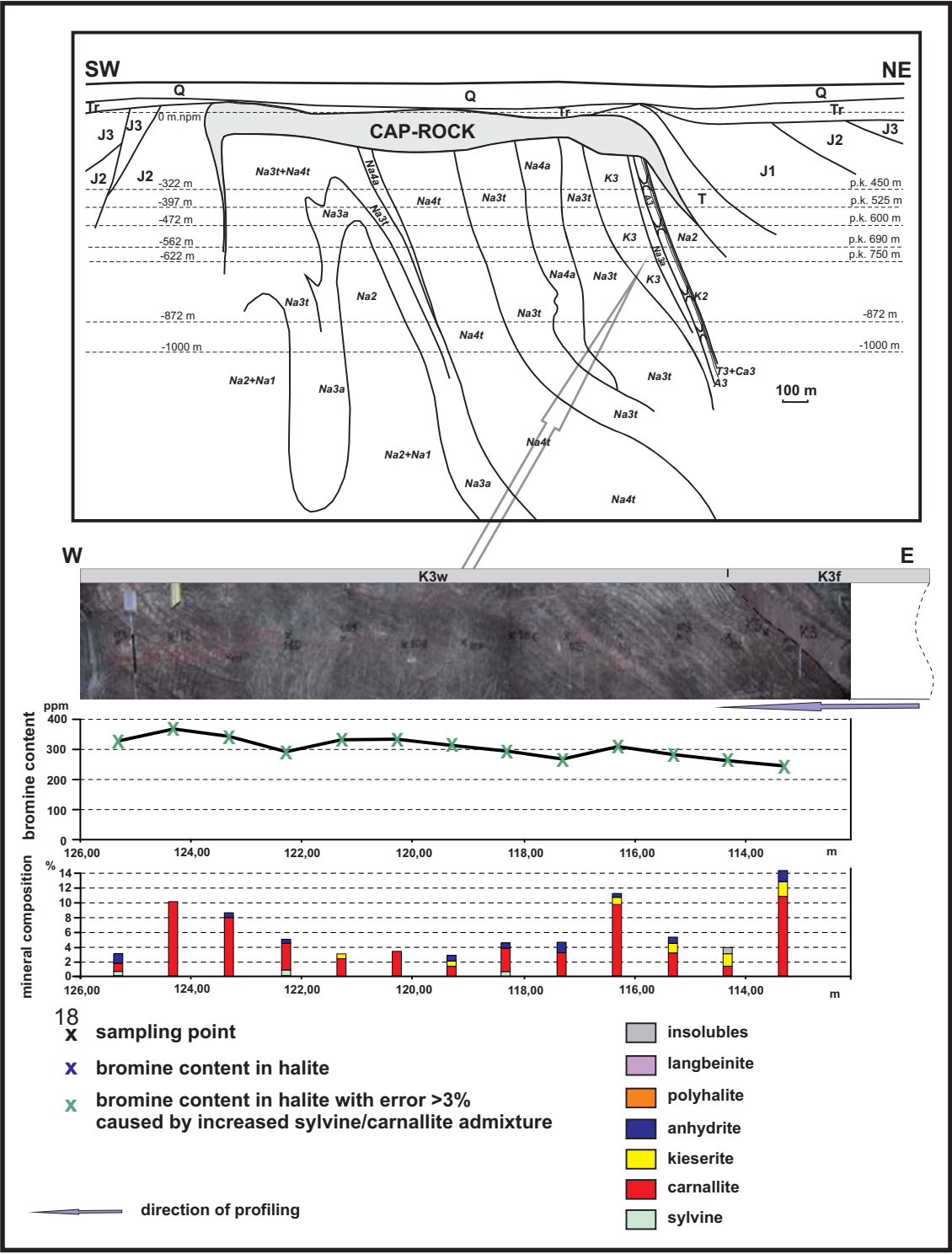

Fig. 4. Schematic geological cross-section of the Kłodawa salt diapir (Burliga 1997) and a fragment of the lithological-geochemical profile of the Younger Potash (K3) unit in the mine gallery at level $-750 \mathrm{~m}$ (Tomassi-Morawiec et al. 2008a). Same explanations as in figure 2; $\mathrm{K} 3 \mathrm{w}$ - stratified subunit of the Younger Potash; K3f - folded subunit of the Younger Potash

Fig. 4. Schematyczny przekrój geologiczny przez wysad solny Kłodawa (wg Burliga 1997) i fragment profilu litologiczno-geochemicznego utworów ogniwa młodszej soli potasowej (K3) w wyrobisku kopalni na poziomie $-750 \mathrm{~m}$ (Tomassi-Morawiec et al. 2008a). Objaśnienia jak na figurze 2; K3w młodsza sól potasowa warstwowana; K3f - młodsza sól potasowa sfałdowana 


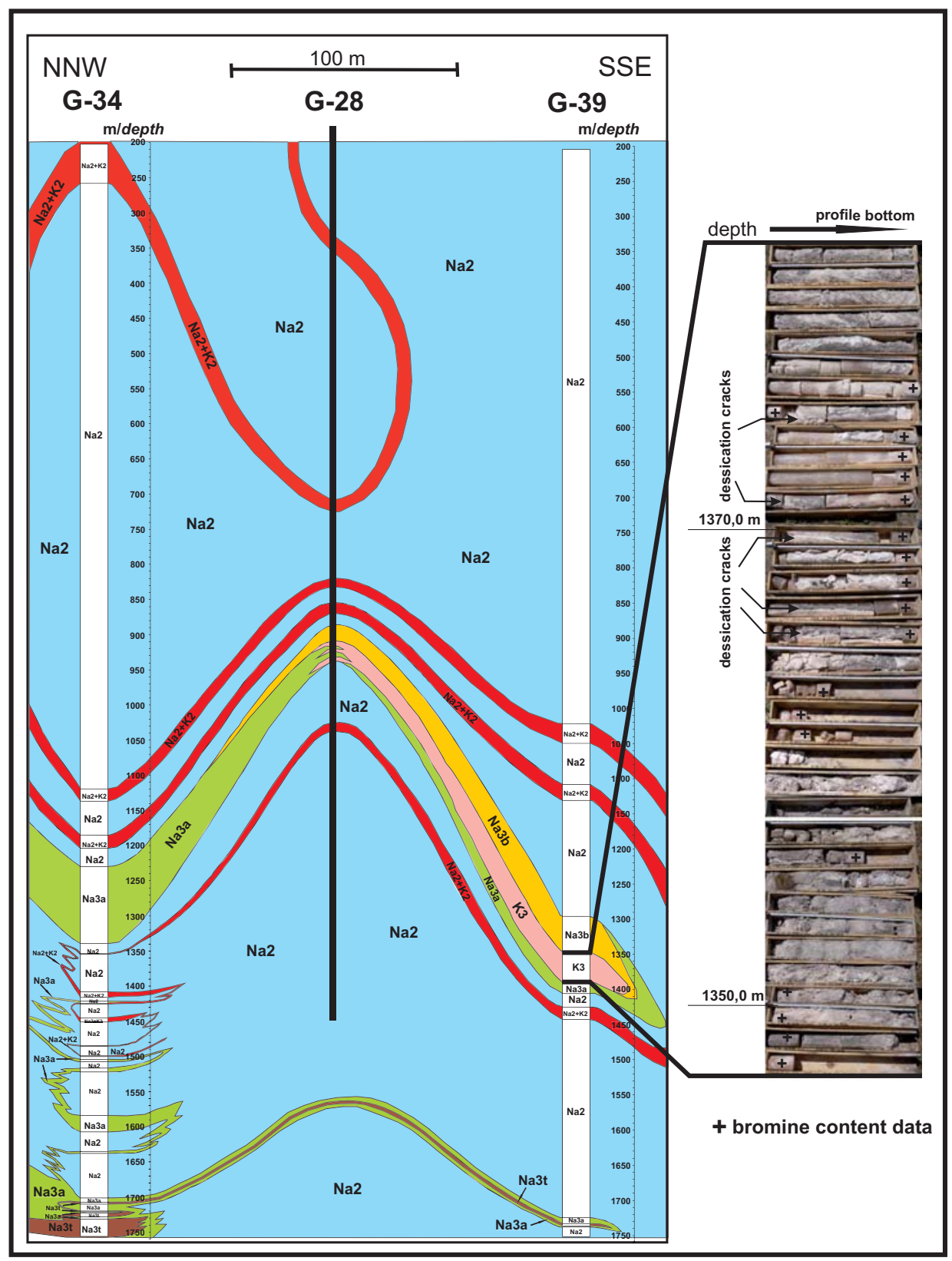

Fig. 5. Geological cross-section of the Góra salt diapir (after Czapowski et al. 2009) and a fragment of the core of Younger Potash (K3) unit profile from G-39 borehole. Same explanations as in figure 2

Fig. 5. Przekrój geologiczny przez wysad solny Góra (wg Czapowski et al. 2009) i fragment rdzenia z profilu ogniwa młodszej soli potasowej (K3) w otworze wiertniczym G-39. Objaśnienia jak na figurze 2 
The highest content of rubidium was characteristic for pure carnallite rocks and nests and veins of secondary potash-magnesium salts. The potash-bearing series from the Lanięta salt diapir were characterised with a much lower proportions of rubidium (17-33.7 ppm) and bromine (181-210 ppm).

\section{Studies of core material from the Góra salt diapir \\ (Tomassi-Morawiec et al. 2008b, Czapowski et al. 2009) (Fig. 5)}

The $\mathrm{NaCl}$ content in the discussed unit was high, reaching from $90.7 \%$ to $99.5 \%$, with bromine content in halite changing from $234 \mathrm{ppm}$ to $649 \mathrm{ppm}$

\section{Data analysis from the Mogilno salt diapir}

Tables 4 and 5 present the statistical parameters of determined chemical components and calculated mineral components on that basis, for 17 channel samples, taken from the Younger Potash unit driiled by the M-24 borehole in the Mogilno diapir. Halite content was varied, from ca. $78 \%$ to ca. $98 \%$ (mean: ca. 95\%). Calcium sulphate (anhydrite) generally accompanied halite, occurred in small quantities not exceeding $1 \%$. The potash content did not exceed $0.5 \%$ (mean content: ca. $0.3 \%$ ). Magnesium content exceeded $0.5 \%$ only in three samples, and the maximum value was $3.927 \%$. Polyhalite occurred in insignificant quantities, while sylvine and carnallite were quite common, although in low concentrations. Sylvine content did not exceed $1 \%$ and carnallite $1.4 \%$. Mean contents of these minerals were $<0.5 \%$. Kieserite was common and its content ranged from $0.7 \%$ to $22.4 \%$, with mean concentration of $3 \%$ (in half of the samples set it did not exceed $1.7 \%$ ).

\section{Comments on geochemical results}

Similarly to the Older Potash unit, the comparison and summarizing of the above presented results of the chemical and mineral composition of Younger Potash unit from the $\mathrm{Ku}-$ jawy region is difficult because of diverse sampling and analytical methods.

The conclusions presented below are rather general:

- halite content in the sampled potash unit in the Kłodawa Salt Mine is much more diverse than in case of equivalent rocks from the Mogilno diapir, and the mean sodium chloride content is lower in the Kłodawa rocks;

- salt rocks from the Kłodawa diapir are characterized by a larger diversity of potash and magnesium content and a their higher mean concentrations in comparison to data from the rock samples taken from the Mogilno diapir, although the median values are similar (comparing the results of point samples);

- anhydrite is a common mineral of the studied rocks, but it less frequent in samples from the Mogilno diapir;

- the Younger Potash unit of the Kłodawa diapir is rich in carnallite and sylvine (sylvine content is lower than of carnallite), analogous rocks from the Mogilno diapir contained small concentrations of these minerals; 
- kieserite occurs irregularly in sampled profiles from the Kłodawa diapir. It is mainly associated with the kieserite-carnallite layers where it reaches high content, while in the rocks from the Mogilno diapir kieserite was common and its content was less diverse;

- polyhalite or langbeinite were found sporadically in the tested rocks;

- bromine content in the studied potash unit was very high in the majority of samples taken from the Kłodawa diapir.

\section{Literature data from wells drilled in the Fore-Sudetic Monocline area}

The Younger Potash (K3) unit was drilled with 20 boreholes, within a $10 \mathrm{~km}$ wide belt extending from Nowa Sól to the Sulechów where it was identified at the depth of 838-1068 m (Podemski 1974, Dawidowski 1976, Czapowski 2006, with references therein).

The 14.4-30.7 $\mathrm{m}$ thick potash unit was composed of two potash-bearing zones, separated with a rock salt series about a dozen of metres thick:

- the upper zone, $12 \mathrm{~m}$ thick (dominat compoments are sylvine, kieserite, polyhalite; $\mathrm{K}_{2} \mathrm{O}$ content: $1-16 \%)$;

- the lower zone, $6 \mathrm{~m}$ thick (rock salt with anhydrite and polyhalite concentrations; $\mathrm{K}_{2} \mathrm{O}$ content: $1-4.5 \%$ ).

Main minerals of the potash series: sylvine, halite, kieserite, and sulphates (anhydrite and polyhalite), represented the secondary salts after primary carnallite ones.

The chemical composition data based on the analyzed 74 samples taken from three boreholes (Podemski 1974b, Werner \& Dawidowski 1976). Main component content values are: $\mathrm{K}_{2} \mathrm{O}-1-16 \%$, mean: 3-9\%; $\mathrm{MgSO}_{4}$ in both zones: $2-49 \%$; $\mathrm{CaSO}_{4}$ in both zones: $<0.5-9.9 \%$; $\mathrm{NaCl}$ in both zones: $18-91 \%$, mostly: 37-97\%; $\mathrm{Br} / \mathrm{Cl}$ index: 0.19-1.2.

\section{PETROLOGICAL CHARACTERISTICS OF POTASH UNITS}

\section{OLDER POTASH (K2) UNIT}

In the microscopic image salts composing the Older Potash (K2) unit both from the Kłodawa diapir (Fig. 6A-C) and from the Inowrocław diapir (Fig. 6D, E) were fairly diverse. Halite was the main mineral, accompanied by small quantities of sylvine. Both minerals were mostly xenomorphic, intergrown, with clearly ragged boundaries, sometimes they are elongated. In difference to halite, sylvine has a quite often a red-brownish rim, probably composed of very fine hematite plates.

Within both minerals, the grains of anhydrite, kieserite, and rarely carnallite and polyhalite occurred in various proportions. Anhydrite and kieserite either created small aggregates or occured as single chaotically dispersed grains (Fig. 6A). Anhydrite was mostly xenomorphic, rarely hipautomorphic. Its grains, $<0.1 \mathrm{~mm}$ to $>0.5 \mathrm{~mm}$ in size, were often strongly corrodes, with ragged boundaries. Kieserite mostly created oval grains, with their size close to those of anhydrite. In some samples its larger aggregates were made of very fine crystals of ca. $0.01 \mathrm{~mm}$, locatedmainly at halite or sylvine crystal margins and creating rims or concentrations over $0.5 \mathrm{~mm}$ thick (Fig. 6B). 
Polyhalite is quite common but it occurred in small amount as aggregates of fibrous or fine plane cystals $0.1 \mathrm{~mm}$ to $1 \mathrm{~mm}$ in size, sometimes radially arranged. They often included relics of anhydrite or kieserite crystals.

Locally appeared the carnallite, creating fine (up to ca. $0.1 \mathrm{~mm}$ ) ingrowths within halite or larger crystals up to 3-4 mm in size (Fig. 6C). Both carnallite forms were usually xenomorphic. Large crystals often possessed corroded and ragged edges and transformation evidences: they were intensely cracked and crushed. Locally are observed kainite or probably bischofite pseudomorphs after carnallite.
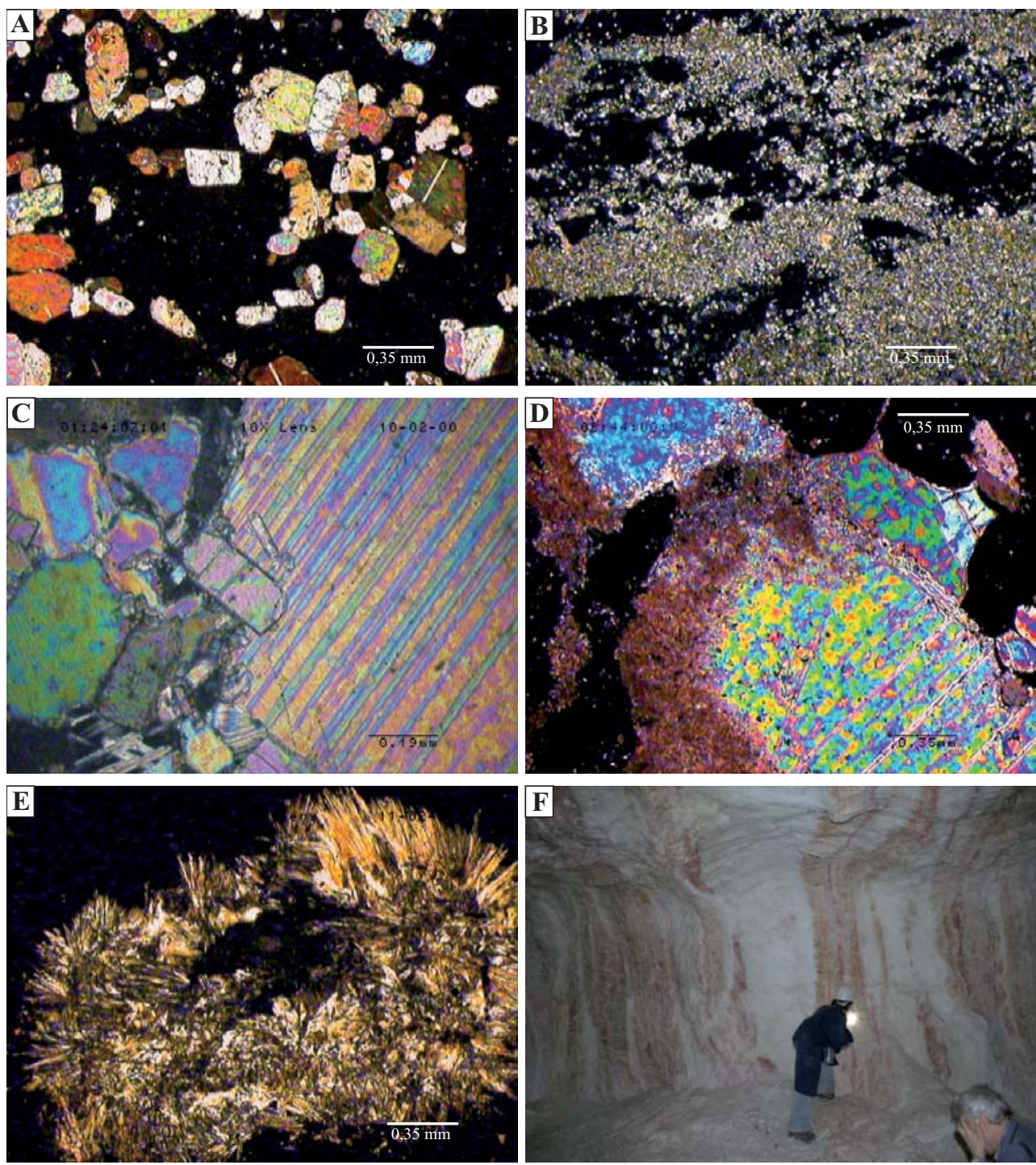
Kieserite-carnallitite from the Older Potash unit in the Inowrocław salt diapir has specific features in the microscopic image. Carnallite grains were xenomorphic, or less often hipauthomorphic, with polysynthetic twinning extending in one or two directions. Transformation of carnallite into bischofite (Fig. 6D) was a frequent phenomenon, best developed at the carnallite and halite contacts but less expressed along twinning planes. Halite accompanied carnallite was usually xenomorphic or hipauthomorphic, often with distinct cube fissility. Sometimes it was slightly contaminated with dispersed clay matter or microscopic hematite plates. Sylvine crystals accompanied locally halite were smaller and very irregular, often with bay-shaped borders.

Within both chloride minerals were found cylindrical kieserite grains $>0.5 \mathrm{~mm}$ in size with often visible double twinning. They created either irregular concentrations composed of several to about a dozen of individuals or were dispersed usually in halite or less often in carnallite.

Anhydrite grains were less often found there than in "hard" salts. Usually they were hipauthomorphic with size similar to that of kieserite grains. Moreover polyhalite concentrations with size often exceeding $1 \mathrm{~mm}$ and composed of columnar, elongated grains spherically arranged (Fig. 6E), were obsereved.

\section{YOUNGER POTASH (K3) UNIT}

Rocks of the Younger Potash (K3) unit from the Kłodawa diapir (Fig. A-C) showed larger petrological diversity, both in vertical and horizontal unit extent, in comparison to the Older Potash complex.

Fig. 6. Petrology of the Older (K2; Fig. 6A-E) and the Younger (K3; Fig. 6F) Potash units from the Kłodawa and the Inowrocław salt mines: A) Kieserite and anhydrite grains occurring in the halite and sylvine matrix. Image at NX, Kłodawa Salt Mine, level 525, corridor N-I. B) The masses and flames at edges of halite and sylvine crystals was composed of very fine crystalline kieserite mass, with small proportion of anhydrite. Image at NX, Kłodawa Salt Mine, level 600, corridor SW VII. C) Large carnallite grain (on right), with polysynthetic twinning; the authomorphic anhydrite crystal (in center) accompanied by cylindrical kieserite grains (on left). Images at NX, Kłodawa Salt Mine, level 525, corridor NE X. D) Carnallite transformations into bischofite. Inowrocław Salt Mine, level IV, corridor 19. E) Radial concentration of polyhalite. Inowrocław Salt Mine, level IV, corridor 19. F) Younger Potash (K3) rocks in the Kłodawa Salt Mine

Fig. 6. Petrologia utworów starszej (K2; Fig. 5A-G) i młodszej (K3; Fig. 5F) soli potasowej z wyrobisk w kopalniach soli w Kłodawie i Inowrocławiu: A) Ziarna kizerytu i anhydrytu występujące w obrębie tła złożonego z halitu i sylwinu. Obraz przy NX, KS Kłodawa, poz. 525, przekop N-I. B) Nagromadzenia i smugi na granicach kryształów halitu i sylwinu zbudowane z bardzo drobnokrystalicznej masy kizerytu z mniejszym udziałem anhydrytu. Obraz przy NX, KS Kłodawa, poz. 600, przekop SW VII. C) Duże ziarno karnalitu (z prawej) z polisyntetycznymi zbliźniaczeniami, w centralnej części obrazu kryształ anhydrytu o automorficznym zarysie, któremu towarzyszą (z lewej) obłe ziarna kizerytu. Obraz przy NX, KS Kłodawa, poz. 525, przekop NE X. D) Przeobrażenia karnalitu w biszofit. KS Inowrocław, poz. IV, chodnik 19. E) Skupienie promieniste polihalitu. KS Inowrocław, poz. IV, chodnik 19. F) Utwory młodszej soli potasowej (K3) w KS Kłodawa 
Kieseritic carnallitite was usually medium-crystalline, less often small- or coarse-crystalline, with rare large halite crystals. Detailed petrographic studies (Hanczke 1969) indicated its variable mineral content, especially in the proportions of particular main minerals, including halite, carnallite, kieserite, and sylvine. Anhydrite occurred there as a subordinate mineral and sporadically also polyhalite, langbeinite, boracite, and quartz.
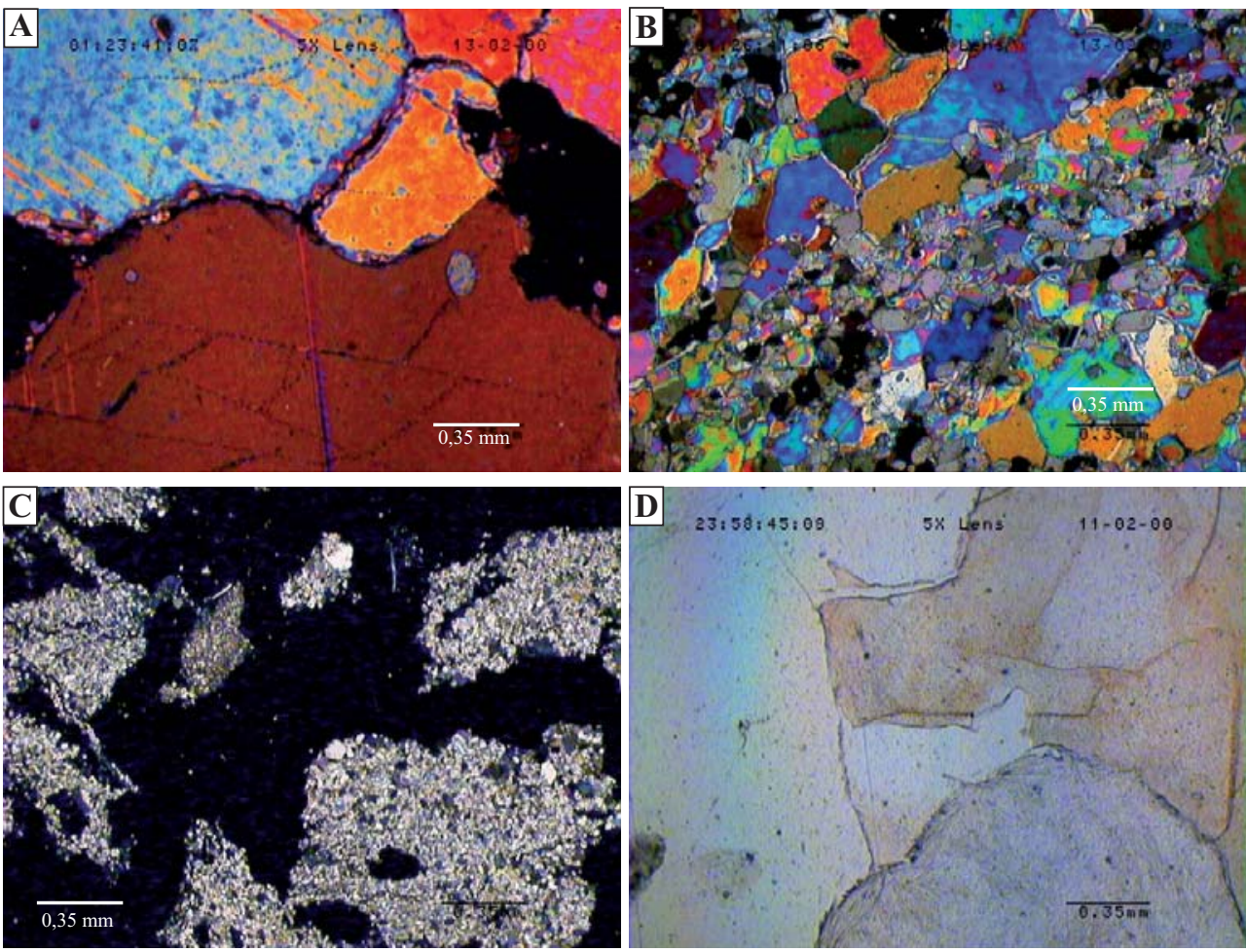

Fig. 7. Petrology of the Younger Potash (K3) salts from the Kłodawa and the Inowrocław salt mines: A) Carnallite grains, with single kieserite ingrowths and fluid inclusion sets. Image at NX, Kłodawa Salt Mine. B) Flames of kieserite within carnallite. Image at NX, Kłodawa Salt Mine. C) Very fine crystalline kieserite concentrations within a halite mass. Image at NX, Kłodawa Salt Mine. D) Halite (transparent) and sylvine (red) crystals, with polyhalite concentration. Image at 1X, Inowrocław Salt Mine

Fig. 7. Petrologia utworów młodszej soli potasowej (K3) z wyrobisk w kopalniach soli w Kłodawie i Inowrocławiu: A) Ziarna karnalitu z pojedynczymi wrostkami kizerytu i zespołami inkluzji fluidalnych. Obraz przy NX, KS Kłodawa. B) Smugowate skupienia kizerytu w obrębie karnalitu. Obraz przy NX, KS Kłodawa. C) Bardzo drobnoziarniste skupienia kizerytu w obrębie masy halitowej. Obraz przy NX, KS Kłodawa. D) Kryształy halitu (przezroczyste), sylwinu (czerwonawe) oraz skupienie polihalitu. Obraz przy $1 \mathrm{X}$, KS Inowrocław

The microscopic image (Fig. 7A-C) of the samples of "pure" carnallititic layers presented the pure carnallite dominant xenomorphic and subordinate authomorphic grains, $0.5 \mathrm{~mm}$ to several millimetres in size (Fig. 7A). Less often than in the Older Potash unit they indicated 
twinning, sometimes with visible fluid inclusion sets, emphasizing fracture systems. These grains contained sporadically single oval kieserite grains with the diameter of ca. $0.1 \mathrm{~mm}$. In thin plates from the kieserite-rich rocks the carnallite grains were often smaller, a bit more over $1 \mathrm{~mm}$ in size (Fig. 7B). Oval kieserite grains up to $0.1 \mathrm{~mm}$ created also the elongated concentrations and falmes, usually located at carnallite grain borders. In some plates, with the dominated halite or sylvine, kieserite very fine grains formed compacted irregular concentrations (Fig. 7C).

The samples of K3 unit from the Inowrocław diapir (Fig. 7D) evidenced the different petrographic image than those from the Kłodawa diapir. This unit was represented mainly by "hard" kieseritic, kainitic, anhydrite-polyhalitic salts, medium- and coarse-crystalline, with chaotic or flame texture (Dyląg 1970, Satanowski 1973, Bednarz \& Pasierb 1974). Their colours were changing from light grey, grey-red to pink, mostly red in case of sylvine, pink in case of polyhalite and grey in case of anhydrite. Halite and sylvine were xenomorphic (Fig. 7D). The sylvine crystal colour was usually associated included very fine, evenly distributed hematite plates. Other mineral components were developed similarly to those of the Older Potash unit.

\section{CONCLUSIONS}

To consider the general geochemical characteristics of both potash-bearing salt units of the Polish Zechstein PZ2 and PZ3 cycles it was absolutely needed to base on the results of rock studies in the Kłodawa salt diapir because these analytical material was the most exhaustive in the number of tested samples and analytical data. Both analytical results of the channel samples (Werner et al. 1962) and of later studies (Tomassi-Morawiec 2008a, 2009) indicated the basic differences in chemical and mineral compositions of rocks representing both lithostratigraphic units.

Halite content in both units was quite diverse. Rocks of the Older Potash (K2) unit from the Kłodawa diapir were enriched in potash and magnesium in comparison to these ones of the Younger Potash (K3) unit. Mean content of both elements in the point samples (Tabs 6, 7) was as follows: potash $-8.56 \%$ (K2) and $1.71 \%$ (K3), magnesium $-2.28 \%(\mathrm{~K} 2$ ) and $1.46 \%$ $(\mathrm{K} 3)$, respectively. Also, the mediane values were higher. Sylvine was the main potash mineral accompanied halite in the $\mathrm{K} 2$ rocks. Its mean content was $8.7 \%$ in the channel samples and $14.3 \%$ in the point samples. Carnallite content in the Older Potash rocks was lower than that of sylvine: its mean concentrations was $2.45 \%$ (in channel samples) and $1.9 \%$ (in point samples). In the Younger Potash rocks the reverse relationships were observed: carnallite dominated over sylvine. Its mean content was $21.25 \%$ (channel samples) and $10.9 \%$ (point samples), with mean sylvine concentrations of $3.8 \%$ and $0.3 \%$, respectively. The quantitative relationships between sylvine and carnallite were confirmed by thin plate analysis of both units.

The Older Potash unit in the Kłodawa diapir was also enriched in calcium and magnesium sulphates such as: anhydrite, kieserite, and epsomite, comparing to the Younger Potash salts. Also polyhalite was more frequent in the $\mathrm{K} 2$ unit.

The rocks of both units were rich in bromine, occurred in halite, sylvine and carnallite. High bromine concent in halites, reaching 300 ppm in the K2 unit and 500 ppm in the K3 unit, 
were typical for the carnallite zone of salt sequence (Kühn 1968) and indicated the primary origin of carnallite. Sylvine was probably a secondary mineral after former carnallite. Also, polyhalite was a secondary mineral replacing anhydrite at the early stage of deposit transformation under the influence of potash and magnesium rich brines. Higher sylvine content in the Older Potash unit and the lower carnallite content there, in comparison to the Younger Potash unit, indicated that the K2 salts became transformed more intensively than those of K3 unit.

The analytical material relating to the potash-bearing rocks from the Gora and the Mogilno salt diapirs was less abundant and consequently less effective for more precise comparisons. Generally, these rocks were characterized by a relatively high and even halite content. Potash and magnesium concentrations were much lower than the respective ones in samples from the Kłodawa salt diapir, and the content of other mineral components (especially of sylvine and anhydrite) was lower as well. For the Older Potash unit the mean carnallite content was similar in all diapirs, but the Younger Potash rocks from the Mogilno diapir was depleted in carnallite comparing to the equivalent rocks from Kłodawa. However, kieserite content of the K3 unit was less diverse and its mean values were higher in rocks of the Mogilno diapir in comparison to those of the Kłodawa structure.

Petrological observations of selected samples of the Older Potash (K2) unit evidenced their variable development in both the Kłodawa and the Inowrocław diapirs. Predominated halite and additional sylvine were mostly xenomorphic, they included dispersed and aggregated xenomorphic or hipauthomorphic grains of anhydrite, kieserite and rarely carnallite and polyhalite. Locally were found xenomorphic large carnallite grains with a polysynthetic twinning. Kieserite-carnallitite samples from the Inowrocław diapir differed evidenced frequent transformation of carnallite into bischofite and radial polyhalite aggregates.

Samples of the Younger Potash (K3) unit from the Kłodawa diapir were petrologically more diverse than those of the Older Potash complex. They were composed - with various proportions - of halite, carnallite, kieserite, sylvine and as subordinate minerals: anhydrite, polyhalite, langbeinite, boracite and quartz. Samples from the Inowrocław diapir evidenced the "hard" kieseritic, kainitic, anhydrite-polyhalitic salts, with admixture of xenomorphic halite and sylvine. In both units sylvine crystals included very fine hematite plates.

\section{REFERENCES}

Bednarz A. \& Pasierb M., 1974. Sole magnezowo-potasowe wysadu solnego w Inowrocławiu. Arch. KGZiG, Wydz. Geologii, Geofizyki i Ochrony Środowiska AGH, Kraków (M.Sc. Thesis).

Braitsch O. \& Herrmann A.G., 1963. Zur Geochimie des Broms in salinaren Sedimenten. Teil I: Experimentelle Bestimmung der Br-Verteilung in verschiedenen naturlichen Salzsystemen. Geochimica et Cosmochimica Acta, 27, 361-391.

Burliga S., 1995. Dessication polygons within the salt deposits of the Kłodawa Salt Mine. Abstracts of XIII International Congress on Carboniferous-Permian, Kraków, Poland.

Burliga S.,1997. Ewolucja wysadu solnego Kłodawy. Mat. Konf. „Tektonika solna regionu kujawskiego", Uniejów 23-25.10.1997, WIND, Wrocław, 1-14. 
Burliga S., Czapowski G., Misiek G., Poborska-Młynarska K. \& Garlicki A., 2004. Możliwości utrzymania produkcji w Kopalni Soli „Kłodawa” oraz koncepcji jej likwidacji $w$ świetle obecnego rozpoznania budowy geologicznej, zagrożeń naturalnych i geomechanicznych skutków wieloletniej eksploatacji. Etap I: Aktualizacja budowy geologicznej wysadu solnego w granicach obszaru górniczego Kopalni Soli „Kłodawa” z wnioskami dla dalszego jej funkcjonowania. Fundacja „Nauka i Tradycje Górnicze”, AGH, Kraków.

Chandij M., 1976. Geochemiczna regionalizacja jakościowa złóż soli w kopalniach kujawskich. Prace Geologiczne PAN Oddz. w Krakowie, 91, 1-80.

Charysz W., 1973. Cechsztyńskie piętro soli młodszych (Z3) w regionie kujawskim (Zechstein stage of Younger Salts (Z3) in Kujawy region). Prace Geologiczne, 75, 1-68.

Czapowski G., 1993. Facies Characteristics and Distribution of the Zechstein (Upper Permian) Salt Deposits of PZ3 (Leine) Cycle in Poland). Bulletin of the Polish Academy of Sciences. Earth Sciences, 41, 4, 229-237.

Czapowski G., 2006. Permskie sole potasowo-magnezowe na obszarze centralnej i południowo-zachodniej Polski - obecny stan rozpoznania. Przeglad Geologiczny, 54, 4, 317.

Czapowski G. \& Bukowski K., 2009. Złoża soli w Polsce: aktualny stan i perspektywy zagospodarowania. Przeglad Geologiczny, 57, 9, 798-811.

Czapowski G., Antonowicz L. \& Peryt T.M., 1991. Facies and paleogeography of the Zechstein (Upper Permian) Older Halite (Na2) in Poland. Bulletin of the Polish Academy of Sciences. Earth Sciences, 38, 1-4, 45-55.

Czapowski G., Tomassi-Morawiec H., Tadych J., Grzybowski Ł. \& Sztyrak T., 2009. Wykształcenie i tektonika utworów solnych cechsztynu w wysadzie solnym Góra koło Inowrocławia w świetle wyników kompleksowych badań geochemiczno-litologicznych w wybranych otworach wiertniczych. Przegląd Geologiczny, 57, 6, 494-503.

Dawidowski S., 1976. Obecne rozpoznanie koncentracji soli potasowych młodszych (K3) w okolicy Nowej Soli i perspektywy ich gospodarczego zastosowania. Przegląd Geologiczny, 24, 9, 545-546.

Doornenbal J.C. \& Stevenson A.G. (Eds), 2010. Petroleum Geological Atlas of the Southern Permian Basin Area. EAGE Publications, Houten, 1-342.

Dyląg E., 1970. Wewnętrzna budowa geologiczna pótnocnej części wysadu solnego w Inowrocławiu. Arch. KGZiG, Wydz. Geologii, Geofizyki i Ochrony Środowiska AGH, Kraków (M.Sc. Thesis).

Hanczke T., 1969. Mineralogia i petrografia soli cechsztyńskich kopalni Kłodawa. Prace Muzeum Ziemi, 16, 3-52.

Garlicki A., 1956. Sole starsze na wysadzie kłodawskim ze szczególnym uwzględnieniem poziomów potasowo-magnezowych. AGH Kraków, CAG PIG nr 39-28/470, Warszawa.

Garlicki A., 1991. On some Root Structures of Zechstein Salt Deposits in Poland. Proceedings of International Zechstein Symposium Hannover - Kassel 1987, Zbl. Geol. Paläont., Teil I, Heft 4, 1211-1222.

Garlicki A., Szybist A. \& Kasprzyk A., 1991. Badania pierwiastków śladowych w złożach soli i surowców chemicznych. Przegląd Geologiczny, 39, 11-12, 520-527. 
Kühn R., 1968. Geochemistry of German potash deposits. Special Paper - Geological Society of America, 88, 427-504.

Mattenklott M., 1994. Die Bromid- und Rubidiumverteilung in Carnallitgesteinen: Kriterien für die Genese mariner Evaporite. Technische Universität Clausthal (dissertation)

Misiek G., 1997. Stratygrafia i wykształcenie utworów cechsztynu w wysadzie solnym Kłodawy. In: Burliga S. (red.), Tektonika solna regionu kujawskiego, Mat. Konf. Uniejów, 23-25 października 1997, WIND - J. Wojewoda, Wrocław, 20-23.

Poborska-Młynarska K., 1984. Paleogeograficzne tło pewnej nieciągłości w sedymentacji cechsztynu salinarnego w regionie kujawskim. Mat. Konf. Nauk. Uniwersytetu A. Mickiewicza, seria geol., 11, 97-98.

Podemski M., 1966. Sole potasowe cechsztyńskiego poziomu starszej soli potasowej (K2) z okolicy Nowej Soli. CAG PIG-PIB nr 4121/191, Warszawa.

Podemski M., 1972a. Cechsztyńskie sole kamienne i potasowe cyklotemów Z2, Z3 w okolicach Nowej Soli. Biuletyn Instytutu Geologicznego, 260, 2, 5-62.

Podemski M., 1972b. Poziom soli potasowej starszej w rejonie Zielonej Góry. CAG PIG-PIB nr 4121/401, Warszawa.

Podemski M., 1973a: Podsumowanie wyników dotychczasowych badań geofizycznych i geologicznych zachodniej części niecki północno-sudeckiej w aspekcie poszukiwań złóż soli kamiennej i potasowej. CAG PIG-PIB nr DS/259, Warszawa.

Podemski M., 1973b. Sedymentacja cechsztyńska zachodniej części monokliny przedsudeckiej na przykładzie okolic Nowej Soli. Prace Instytutu Geologicznego, 71, 1-101.

Podemski M., 1974a. Stratygrafia utworów cechsztyńskich zachodniej części niecki północno-sudeckiej. Kwartalnik Geologiczny, 18, 4, 729-748.

Podemski M., 1974b. Wyniki dotychczasowych badań soli potasowych w strefie przedsudeckiej. Przegląd Geologiczny, 21, 1, 7-12.

Podemski M., 1975. Sole cechsztyńskie w rejonie struktury Rybaki. Biuletyn Instytutu Geologicznego, 286, III, 5-63.

Satanowski L., 1973. Złoża soli w pótnocnej części wysadu inowrocławskiego. Arch. KGZiG, Wydz. Geologii, Geofizyki i Ochrony Środowiska AGH, Kraków (M.Sc. Thesis).

Stańczyk-Stasik I., 1976. Utwory epigenetyczne w kopalniach soli regionu kujawskiego. Prace Geologiczne PAN Oddz. w Krakowie, 90, 1-64.

Tarka R., 1989. Thermal Polygons in the Zechstein Salt. Bulletin of the Polish Academy of Sciences. Earth Sciences, 37, 1-2, 57-61.

Tomassi-Morawiec H., Czapowski G., Toboła T., Iwasińska-Budzyk I., Narkiewicz W., Misiek G., Janiów S. \& Chęciński R., 2008a. Wzorcowe profile bromowe jako obiektywne narzędzie dla ustalenia wieku i podziału wewnętrznego ogniw solnych cechsztynu z obszaru Polski (opracowanie merytoryczne z realizacji projektu badawczego, grant KBN nr 4T12B 002 29). CAG PIG-PIB, Warszawa.

Tomassi-Morawiec H., Czapowski G. \& Sztyrak T., 2008b. Opróbowanie geochemiczne rdzeni z utworów solnych cechsztynu w otworach wiertniczych G-34, G-39 i G-16 zlokalizowanych w KS i PMTiP „Góra”. Archiwum IKS Solino SA, Inowrocław. 
Tomassi-Morawiec H., Czapowski G., Bornemann O., Schramm M. \& Misiek G., 2009. Wzorcowe profile bromowe dla solnych utworów cechsztynu w Polsce. Gospodarka Surowcami Mineralnymi, 25, 2, 75-143.

Wachowiak J., 1992. Nowe spojrzenie na możliwości eksploatacji i wykorzystania soli potasowo-magnezowych w wysadzie solnym „Kłodawa”. Przegląd Geologiczny, 40, 7, 480-485.

Wagner R., 1994. Stratygrafia i rozwój basenu cechsztyńskiego na Niżu Polskim. Prace PIG, $146,1-71$.

Werner Z. (Ed.), 1962. Dokumentacja geologiczna złoża soli potasowo-magnezowych $i$ soli kamiennej $w$ kłodawskim wysadzie solnym, kat. rozp. $B+C_{1}+C_{2}$. CAG PIG-PIB nr 39-27/209, Warszawa.

Werner Z. \& Dawidowski J.S., 1976. Poszukiwanie złóż soli potasowych na monoklinie przedsudeckiej. A/73 Podsumowanie wyników I etapu i projekt dalszych prac poszukiwawczych soli potasowych $w$ rej. Nowej Soli. CAG PIG-PIB nr 4121/140, Warszawa.

Werner Z., Poborski J., Orska J. \& Bąkowski J., 1960. Złoże solne w Kłodawie w zarysie geologiczno-górniczym (A geological and mining outline of the Kłodawa salt deposit). Prace Instytutu Geologicznego, 30, II, 467-495.

\section{Streszczenie}

Praca prezentuje ogólną charakterystykę, geologiczną, geochemiczną i petrologiczną, utworów potasonośnych budujących ogniwa litostratygraficzne - starszą (K2) i młodszą (K3) sól potasową - odpowiednio w obrębie cykli PZ2 i PZ3 cechsztynu w Polsce. Charakterystykę oparto na wynikach prac archiwalnych i materiałach publikowanych, odnoszących się przede wszystkim do profili tych ogniw z czterech wysadów solnych w środkowej Polsce: Góra, Kłodawa, Mogilno i Inowrocław (Fig. 1, 2, 4, 5) oraz uzupełniono o dostępne dane z obszaru przedsudeckiego (Fig. 3). Najobfitszy materiał analityczny dotyczy utworów opróbowanych w wierceniach i w Kopalni Soli Kłodawa w wysadzie kłodawskim (Fig. 2, 4, Tab. 1). Poza omówieniem wykształcenia utworów każdego z ogniw, nacisk położono na porównanie ich składu chemicznego i mineralogicznego.

W wysadzie kłodawskim zawartość halitu w obu wydzieleniach jest dość zróżnicowana (Tab. 2, 4, 6, 7). Utwory starszej soli potasowej (K2; Fig. 2) są bogatsze w potas i magnez (Tab. 6, 7) w porównaniu z utworami młodszej soli potasowej (K3; Fig. 4). Zawartość średnia obu pierwiastków w próbkach punktowych (Tab. 6, 7) wynosi odpowiednio: potas - $8.56 \%$ (ogniwo K2) i $1.71 \%$ (ogniwo K3), magnez - 2.28\% (ogniwo K2) i 1.46\% (ogniwo K3). Wyższe są także wartości median. Głównym minerałem potasowym, który towarzyszy halitowi w osadach ogniwa K2, jest sylwin. Średnia zawartość tego minerału w zbiorze próbek bruzdowych wynosi $8.7 \%$, a w zbiorze próbek punktowych - 14.3\%. Zawartość karnalitu w utworach starszej soli potasowej jest niższa niż sylwinu - jego średnie koncentracje to: $2.45 \%$ (próbki bruzdowe) i 1.9\% (próbki punktowe). W utworach młodszej soli potasowej obserwuje się odwrotne relacje - karnalit przeważa nad sylwinem. Średnia zawartość tego 
minerału w zbiorze próbek bruzdowych wynosi 21.25\%, a w zbiorze próbek punktowych $10.9 \%$, a średnie koncentracje sylwinu to odpowiednio: $3.8 \%$ i $0.3 \%$.

Utwory starszej soli potasowej w wysadzie kłodawskim są także bogatsze w stosunku do utworów młodszej soli potasowej w siarczany wapnia i magnezu, np. anhydryt, kizeryt i epsomit. W skałach solnych ogniwa K2 częściej też spotykany jest polihalit (Tab. 6, 7).

Skały reprezentujące oba wydzielenia są bardzo bogate w brom (Tab. 2, 3, 6, 7) występujący w halicie, sylwinie i karnalicie. Wysokie koncentracje bromu w halitach (do $300 \mathrm{ppm}$ w ogniwie K2 i 500 ppm w ogniwie K3) wskazują na pierwotne pochodzenie karnalitu. Sylwin jest prawdopodobnie minerałem wtórnym, pochodzącym z przeobrażenia wcześniejszego karnalitu, podobnie polihalit powstał kosztem anhydrytu pod wpływem solanek bogatych w potas i magnez. Wyższa zawartość sylwinu w utworach starszej soli potasowej, a niższa - karnalitu w porównaniu z utworami młodszej soli potasowej (Tab. 6, 7), wskazuje na większy stopień ich przeobrażenia.

Znacznie uboższy materiał analityczny z odpowiednich utworów potasonośnych z wysadów Góra i Mogilno (Fig. 5, Tab. 2-5) był dość trudny do porównania z materiałem z wysadu kłodawskiego. Generalnie utwory potasonośne z wysadów Góra i Mogilno charakteryzują się dość wysoką i wyrównaną zawartością halitu. Koncentracje potasu i magnezu są znacznie niższe niż w odpowiednich utworach z wysadu kłodawskiego, niższy jest też udział pozostałych składników mineralnych (zwłaszcza sylwinu i anhydrytu). W przypadku utworów starszej soli potasowej średnia zawartość karnalitu jest zbliżona we wszystkich wysadach (Tab. 3), utwory młodszej soli potasowej z wysadu Mogilno są uboższe w karnalit w porównaniu ze skałami z Kłodawy (Tab. 5). Z kolei zawartość kizerytu w utworach ogniwa K3 jest mniej w zróżnicowana i przeciętnie wyższa w skałach z wysadu Mogilno w porównaniu z wysadem kłodawskim.

Zawartość głównych składników w odpowiadających wiekowo utworach potasonośnych z obszaru monokliny przedsudeckiej mieści się generalnie w przedziałach ich udziału w omawianych ogniwach z centralnej Polski.

Obserwacje petrologiczne wybranych próbek z utworów obu ogniw z wysadów Kłodawa (Fig. 6A-C, F, 7A-C) i Inowrocław (Fig. 6D-F, 7D) wskazują na zmienną budowę tych skał. W przypadku ogniwa K2 z wysadu kłodawskiego (Fig. 6A-C) dominujący halit i podrzędny sylwin są kseromorficzne, zawierają rozproszone i skupione kseno- i hipautomorficzne ziarna anhydrytu, kizerytu, rzadziej karnalitu, kainitu i polihalitu. Obserwuje się też polisyntetyczne zbliźniaczenia dużych ziaren karnalitu (Fig. 6C). Z kolei skały z wysadu inowrocławskiego wykazują obecność pseudomorfoz biszofitu po karnalicie (Fig. 6D) i radialnych skupień polihalitu (Fig. 6E).

Z kolei skały ogniwa K3 w wysadzie kłodawskim są petrologicznie bardziej zróżnicowane (Fig. 7A-C) niż utwory starszego ogniwa. Zbudowane są w różnych proporcjach z halitu, karnalitu, kizerytu, sylwinu, podrzędnie występuje anhydryt, polihalit, langbeinit, boracyt i kwarc. W wysadzie inowrocławskim ogniwo to budują tzw. twarde sole kizerytowo-, kainitowo-, anhydrytowo-polihalitowe, z domieszką kseromorficznego halitu i sylwinu (Fig. 7D). Kryształy sylwinu w skałach obu ogniw litostratygraficznych zawierają bardzo drobne płytki hematytu. 